\title{
Publication Trends and Methodological Advancements in the Area of Agency Cost
}

\author{
Mehreen Furqan * \\ Lahore School of Economics, Lahore, Pakistan \\ Maha Ejaz \\ Lahore School of Economics, Lahore, Pakistan
}

\begin{abstract}
:
The paper presents a systematic literature review of the Research done in the last 30 years in the area of Agency Cost. It undertakes content analysis technique for the purpose and does a complete publication and methodological analysis to discuss the path the research is following. Simple counts and cross tabs are run to look at the advancements in the publication and methodology of the research over the years and in the four different regions of the world where this research is taking place. The results help us determine where and how most of the research in the world is taking place, as in what are its characteristics. The implication of this would be to use the characteristics to do further research in the area of Agency Cost. Also, this research would help in identifying the gaps in the methodology used to research for Agency Cost creating room for further research.
\end{abstract}

Keywords: Agency Cost, Publication Trends, Cost implication

Page: 57 - 86

*Email: mehreena@lahoreschool.edu.pk

P - ISSN: 2313-1217 @ 2014 Sukkur Institute of Business Administration - All rights reserved 


\section{Introduction}

After one decade of entering into the $21^{\text {st }}$ century the importance of academic research is forever on an increase internationally as well in developing nations. Research is now being encouraged in every field whether it is the social sciences or pure sciences.

This paper attempts to study the type of research being done in the area of Agency Cost. It takes into account the different methodologies used to study this problem, considering how these methodologies changed over the years and how researches are done in different areas of the world differ in their use of methodology.

This research also attempts to look at the publication trends of the research being done in the area of Agency Cost. It helps us to identify which regions of the world are publishing more research by academicians and which regions are encouraging researches from practitioners. Also, it helps us identify how author collaboration is changing over the years in different parts of the world. Another important aspect studied in this research is the analysis of the disciplines in which the research in Agency cost is mostly taking place. An analysis based on the ratings of the Journals is also done where the research on Agency Cost is published, studying the changes over the years and in different regions of the world.

Generally in publications we do not find a lot of systematic literature reviews in our area of "Agency Cost". The type of qualitative research, that is present in this area, other than the explanation of the theory, is whether this theory should be taught to students or not by discussing its pros and cons as done by Cohen and Webb (2006) and Heath (2009). Mcdonald (1984) did try to incorporate the direction that the theory of agency cost was going to take, but did not do any empirical testing to base his ideas on. Quantitative researches, on the other hand are numerous, but all are testing the theories of agency cost.

Though this technique of a systematic literature review is being used for other topics in finance, such as in sustainability reports by Borkoski et al. (2012) and of journals such as Financial Services Review by Hanna et al. (2011), it is still missing in the area of Agency Cost, or related theories. This could be probably because a lot of literature research was not encouraged previously. As explained by Sutton (1997) a lot of qualitative research was to be part of "closet research" and was not explained in papers as the journals did not encourage publications of articles that had a lot of qualitative research in them. But the importance of qualitative research exists forever as quantitative research can only be built upon the proper qualitative basis as explained by Sutton and Staw (1995). Thus, considering qualitative research as a building block for further research, this paper moves on a systematic review of the publication trends of the work done in the area of Agency Cost and for this purpose the technique of content analysis is used, which combines the qualitative research with quantitative research.

The main research questions that this paper tries to answer are:

1. What are the Publication Trends of journal articles such as authorship and discipline over the years and regions of the authors? 
2. What are the Methodological trends in the region of author over time?

3. What are the trends in the journals being rated highly and the region where the articles are researched?

\section{Background of Theory of Agency Cost}

Agency Problem is a conflict of interest between two parties. The concept of agency cost was first introduced by Jensen and Meckling (1976). They explained it through the effort required to try and increase the value of the firm. The increased value would benefit the shareholders while the managers might want to replace the effort by their own leisure or over-indulgence in company perquisites. Jensen and Smith (1985) identified three possible areas of conflict between the management and the shareholders. The first area is the effort required by the management to increase the value of the firm. Secondly, risky investments would probably increase the returns for shareholders, as high risks lead to high returns, while the risk for them is minimized because of their diverse portfolio of investments. On the other hand, the risk would be maximized for the managers as they are associated with that firm only and the risk of the firm is directly related to them and so they would not want to take on such a risky investment (Fama, 1980). Even this is directly going to reduce the value of the firm which will not be good for the shareholders. Thirdly, since the managers are part of the firm for a shorter time period than the shareholders they would be interested in investments that would benefit the firm in the near future only and this might not be in the best interest of the shareholders (Furubotn and Pejovich, 1973; Jensen and Meckling, 1979). Thus, if managers engage in self-interested behavior, the firm is not going to perform at its optimal level and this will be against the interests of the shareholders and so the problem of agency is going to arise.

Agency costs most commonly exists in corporations in which owners are separate from management, but with time the agency theory is also being applied in a number of other cases as well where principal - agent exists and there might be a conflict in their interests for example in sports as researched by Atkinson et al. (1988) and McClure and Spector (1997) or drug prescriptions by physicians as explained by lizuka (2007). It can also exist in real estate business as explained by Graff and Web(1997) and also in politics as shown by McGuire and Ohsfeldt (1989), Jensen (2005), Gailmard et al. (2009) and Leaver(2009).

Thus, this paper will move on to consider all such research in which the agency theory is being applied in any scenario.

\section{Methodology}

Content Analysis is a literature review tool that is becoming quite popular because of its contribution to literature. Botha et al (2011) explain its advantages as "First, it can act as a guide to potential authors with regards to changes in content, methodology and article length that can help direct their future publications. Second, the study of historical trends reveals new opportunities for the journals that have hitherto remained unexplored." (p.g. 89)

Content Analysis is being used in a lot of areas other than finance. Brereton et al. (2006) introduced the systematic literature reviews in the domain of software engineering and confirmed them to be as 
important to that field as the literature reviews in medicine would be to theirs. A lot of similar research is being done in the field of management and marketing, such as Gerhard et al. (2011). Even in education department $\mathrm{Wu}$ et al. (2010) have undertaken such research. Similarly, a systematic literature review should be as helpful in Finance and Accounting with the progressing developments in this field. Bisman (2010) stressed on the "postitivist philosophy of critical realism" in which he explained the role of critical realism in research in accounting as a link between qualitative and quantitative research.

\subsection{Selection of Article / Sample}

The database selected for this research is EBSCOHOST, and within it, The Business Source Premier is taken. "Agency Costs" was the term used to search for all the published articles. The criteria given was that the articles should be academic articles published in journals. Also the time frame was set from 1980 till date. This was because the concept of agency cost was first introduced in 1976, so the substantial research that would be done in the area would start after two to three years. Thus, the decades in this analysis starts from 1980s. Also, only full text articles were selected so that they should be completely available for an in-depth analysis.

The search resulted in 341 articles. These articles were shifted to Refworks, a software used for reference management, which converted these articles in a complete bibliography list in excel. The list consisted of all the details of the articles such as their title, author, abstract, publication etc.

\subsection{Coding}

Then a complete coding of the articles took place. The first step of the coding was to code the article as relevant or not. Since the topic was a broad one and the search was done in the abstract and title only, most of the articles were relevant. Any article that discussed the problem of Agency costs or existence of agency costs were considered to be relevant. Articles that were considered to be irrelevant were the ones that discussed different costs or optimal costs related to different companies or agencies. Thus, out of 341,315 articles were found to be relevant.

The second step was to code the articles as being conceptual or empirical and then being qualitative or quantitative based on the criteria given by Minor et al (1993) and Dangayach and Deshmukh (2001) in the area of Manufacturing Strategies. Conceptual studies are studies based on secondary data or working with research already done or theory already built Empirical studies on the other hand used primary data or interprets or derives certain results.

Creswell (1994) explained quantitative research to be dealing with variables, numbers or statistical analysis while qualitative research was explained by understanding of something existing through words, theory etc.

Thus, the research started with four main types of articles as explained by Nakata and Huang (2005) and Page and Schirr (2008) Conceptual Qualitative and Conceptual Quantitative, Empirical Qualitative and Empirical Quantitative. 


\subsection{Final Sample}

The coding of 315 articles resulted in the following:

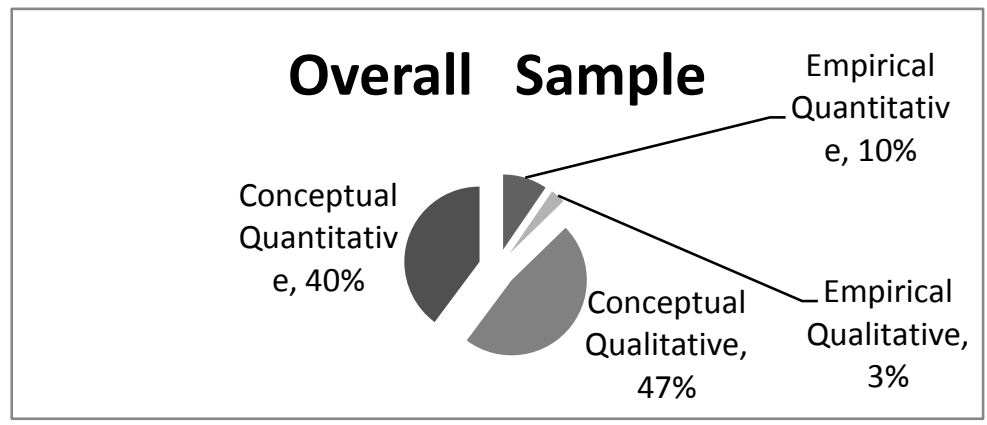

Figure 1: Type of Article

Conceptual Qualitative articles are not considered in this research as they do not have empirical methodology. The most important segment after that (40\%) are those of Conceptual Quantitative articles and thus this research further moves on to analyze these articles. In marketing research, more emphasis is on primary data and thus more empirical papers exist. In finance since a lot of numbers are involved and they come in through secondary sources a greater number of conceptual research exists. Empirical qualitative and empirical quantitative papers are not being considered because their weight age is very low in the overall sample and their methodologies are completely different from that of conceptual papers so the empirical papers cannot be compared with the conceptual papers.

\section{Publication Trends}

The main aim of this paper is to analyze the research being done in the area of agency cost, and so the first part of the analysis is to study the trends in the publications of the research being done. All the aspects being analyzed are being considered over the years and the regions of publications. For this purpose crosstabs are run under each aspect being considered. The time is taken as the publication year of the research paper. It is divided into three decades, 1980s, 1990s and 2000s are till date.

The region is the area that the author is based in. As there are some collaborations between authors, the analysis will also be covering the two major regions of collaboration, as discussed below. The region of the authors are primarily being divided into United States of America (USA), Europe, Asia and Others. Adhikari et al. (2002) in their article divided the regions between US and Non US, but in this research as Europe, which includes United Kingdom, and Asia also had an important amount of research being done, were treated as separate regions. The category of others included some work being done in Australia and Canada. The two main collaborations that were found to take place were between USA and Europe and Asia and USA. The need for collaboration came in to bring in the impact of the articles that had authorship collaboration between different countries. Figure 2. shows that that almost $82 \%$ of the articles are single authored while only $16 \%$ are multiple authored (the remaining $2 \%$ data was not available). 
Mehreen et al. / Publication Trends and Methodological Advancements

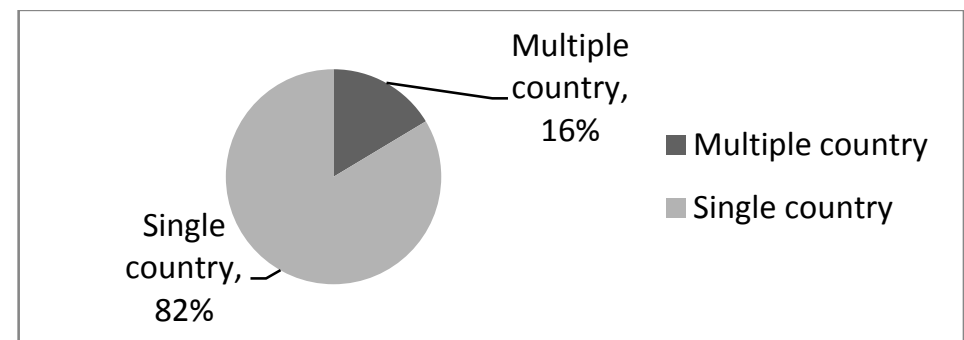

Figure 2: Authorship Collaboration

Percentages for all parts are calculated out of the total research done in that time period and/or in that region.

Figure 3 shows the total counts of the publications in each geographical area over the years. It can be seen clearly that the research in Asia is gaining strength, especially in 2000s. It is also more than the work being done in Asia with the collaboration of the USA. If we look at the details of Asia alone, we find that the major chunk of work being done within Asia is in Korea and Japan with some research being done in China, Indonesia, Malysia and India. A very interesting conclusion can be derived from this graph that in the area of agency cost some work was being done in the 1980s in Asia but nothing was published in Europe during that time.

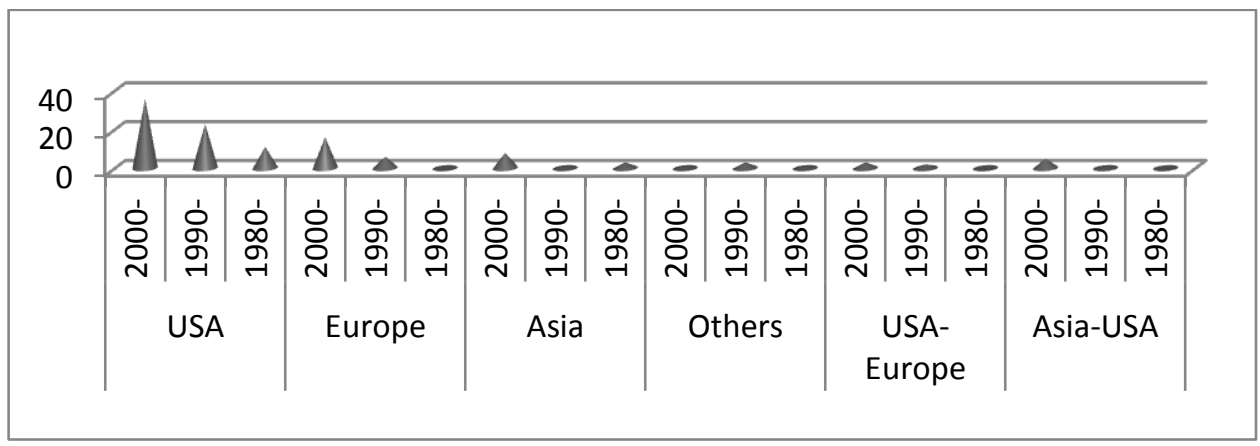

Figure 3: Total Studies done region wise over the years

\subsection{Authorship}

Authorship can be analyzed from two different aspects. The first is the type of authors. Whether the authors belong to the academic fields are they practitioners or is there a collaboration between the two. The second is the number of authors of a paper according to work being done in different regions over the years.

Figure 4 helps us analyze the type of authors. We can see that it is mostly the academicians who are working more in this area in all regions. The practitioners are working independently or in collaboration more in the USA. The reason for this could be because firstly we are considering academic research published in academic journals only so the contribution by the practitioners might be less. Another reason is that almost all the practitioners belonged to the World Bank or companies existing in America making it easier for them to contribute to the journals in USA. 
An Interesting finding is that in 2000s the trend of collaboration between the academicians and practitioners is almost nil in USA, even though it was around 5\% in 1980s and 1990s, but practitioners in USA are contributing through collaboration with Asian writers in 2000s. this could probably be because as it was seen previously, major part of research is being done by academicians is in Asia while majority of practitioners are from USA, thus their collaboration is created.

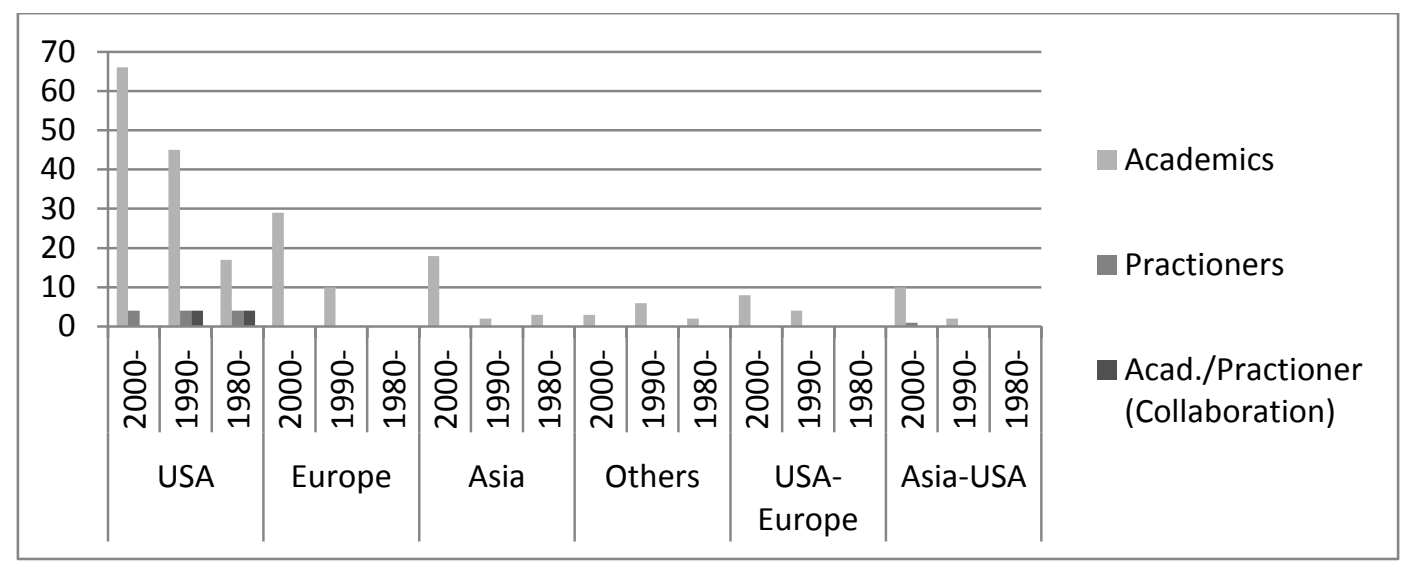

Figure 4: Authorship Type region wise over the years.

Figure 5 explains the trend of the number of authors over the years in different regions. The percentage represents the amount out of the total work done in that region during the time. In the 1990s, almost all the research being done in Asia was single authored which shifted in 2000s to two and three authors as well. Very interestingly, in USA single authored research is the lowest in all years (and two authors highest) while in Europe the single authored research is the highest in 1990s and 2000s. In other countries the trend has shifted from 100\% single authored research to $100 \%$ three authored research. The reason for the increasing number of authors could be to try and bring in more specialized people (in their fields) together in a research to make it more versatile.

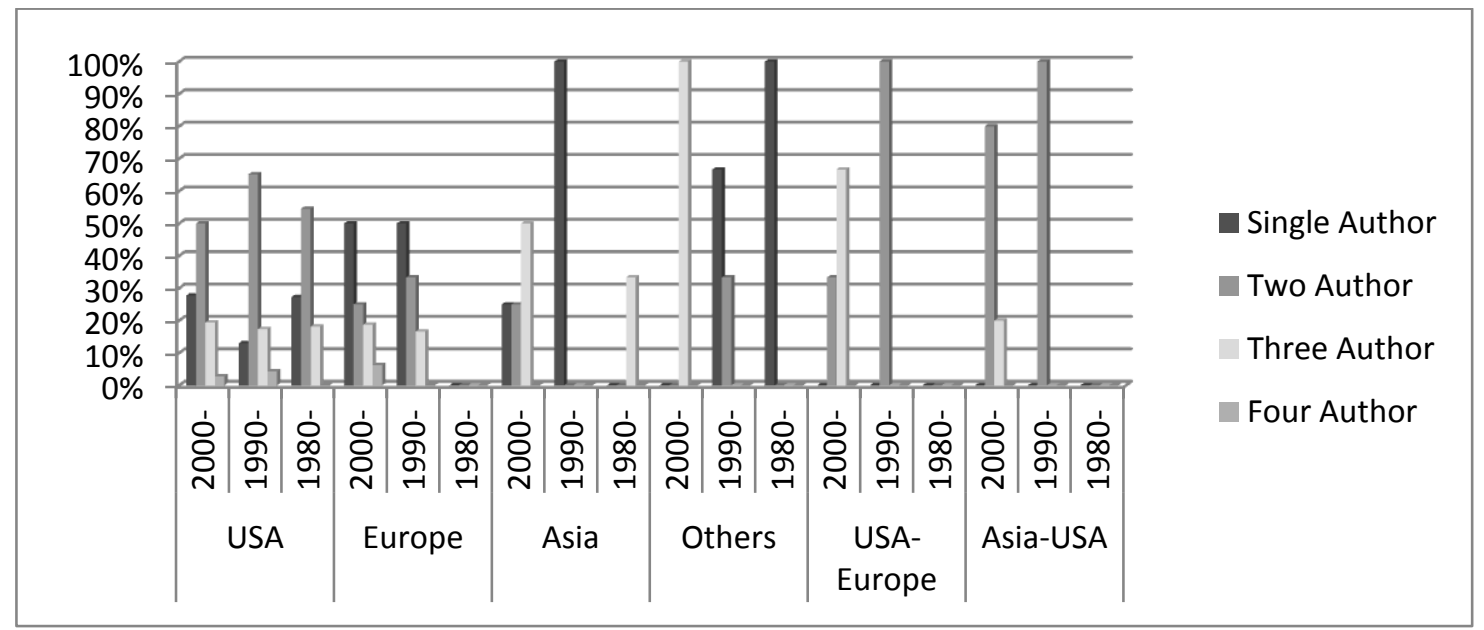

Figure 5: Number of Authors region wise over the years 


\subsection{Journals}

Analysis on the research being published is also done on the basis of the type of journals this research is published in. For this purpose the journals are divided upon the basis of their ratings. These ratings are made on the basis of Anne Wil Harzing's complied list. From the list the rating by Australian Business Deans Council (ABCD 2012) is considered. This lists divides the journals in four categories $\mathrm{A}^{*}, \mathrm{~A}, \mathrm{~B} \mathrm{C}$.

Figure 6 helps us analyze the trend of publications in different journals. A very interesting finding of this part is that a major percentage of articles published by Asian authors are in the top tier $\left(\mathrm{A}^{*}\right)$ journals in the 2000s (around 40\%) against contrary believe that it is very difficult for Asians(Koreans, Japanese, Chinese etc) to get their research published in good journals. This is also a complete shift from 1990s when $100 \%$ research was being published in C rated Journals. Interestingly in USA, the trend shifted from A* journals, as in 2000s a lesser amount of articles are being published in those journals (from $50 \%$ to almost $30 \%$ ) and publication in A category journals increasing. A* journals preferred most articles from a collaboration of Asian and American writers in 1990s and 2000s. For authors from Europe, A class journals were the highest publishers in 2000s and 1990s.

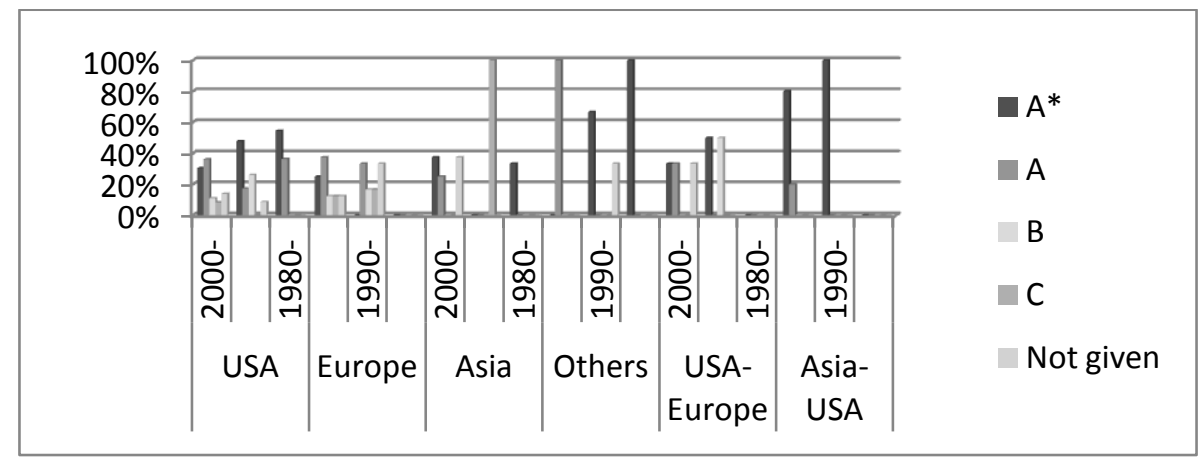

Figure 6: Journal Ratings for publications region wise over the years

\subsection{Discipline}

Another important area for analysis is the disciple in which Agency cost is studied most. As explained earlier, it exists mostly in corporations so the area of research should be Finance or accounting. But, as explained previously, the theory of Agency Cost is also being applied in a number of other real life scenarios. Thus, studying the discipline of research would enable us to learn about its application in other disciplines.

Figure 7 helps the analyses of the discipline in which the concept of Agency Cost is studied the most. As hypothesized, Agency Cost does belong to the area of Finance \& Accounting but surprisingly, it is also being applied to the area of Economics. In Asia, all the research done in 1990s in agency cost was in the discipline of Economics. Even in 2000s, it is mostly in Economics but is gaining strength in the discipline of marketing as the area of marketing is also developing. In the developed nations, like USA and Europe, the theory is also moving in other disciplines such as General and Strategy and Entrepreneurship. Thus, it is not a topic of Finance and Accounting alone anymore. 
Mehreen et al. / Publication Trends and Methodological Advancements

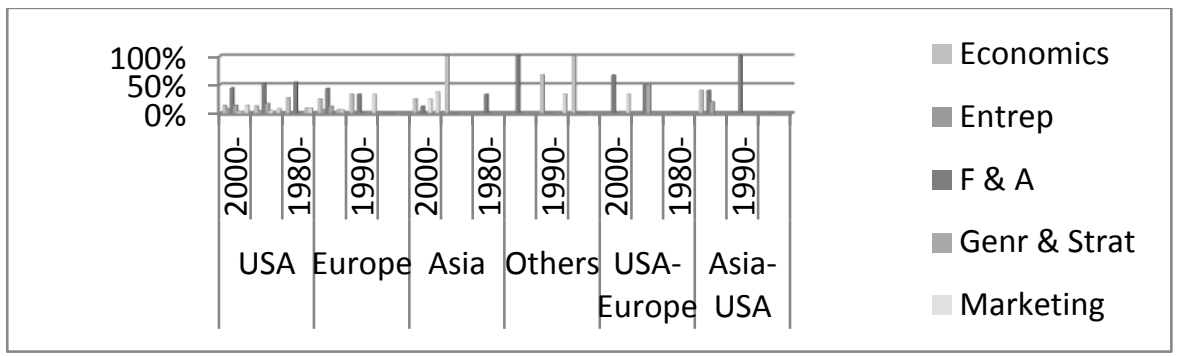

Figure 7: Disciple of Journal of publication Region wise over the years

\section{Methodological Advancements}

Another important analysis to be done in this research paper is to study the advances in different methodologies used in the research being done in the area of Agency Cost. For this purpose the researcher will be looking at two aspects simultaneously, where required. One will be the different methods used in the last three decades and the other will again be the trend in methodological advancements over time in different regions. For this section the collaborations of the authors have not been separated but are part of the total research being done in each region.

\subsection{Research Design}

The most common method of research used worldwide is modeling (as shown in figure 8) and it has been so over the years, followed by simple statistical techniques.

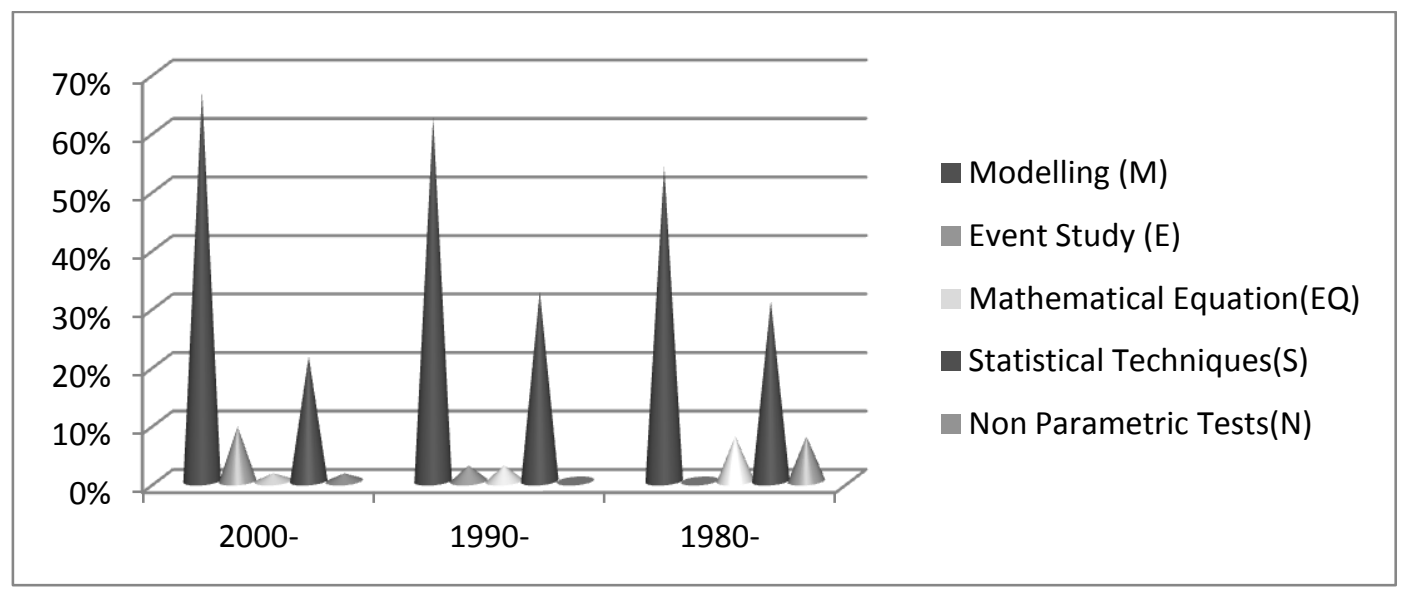

Figure 8: Research Design over the years

In the modeling methodology, a model is estimated and then it is run on the data collected to be tested. This research has identified a number of other research designs and their increased trend of usage. Some papers were found to use the event study research design while some were found to be estimating Mathematical equations. Usage of Event studies has increased a bit in 2000s while that of Mathematical Equations is found to be diminishing over the years. Some papers were also found to be using only simple statistics to prove their point, but their usage has decreased in the $21^{\text {st }}$ century. There were also some nonparametric tests used in 1980s but their use is almost finishing now. 
The analysis in this paper (figure 9) shows that all the research being done in Asia in 1980s and 1990s was using the modeling design. In 2000s, the event study design is being used with a high percentage and also statistical techniques to some extent.

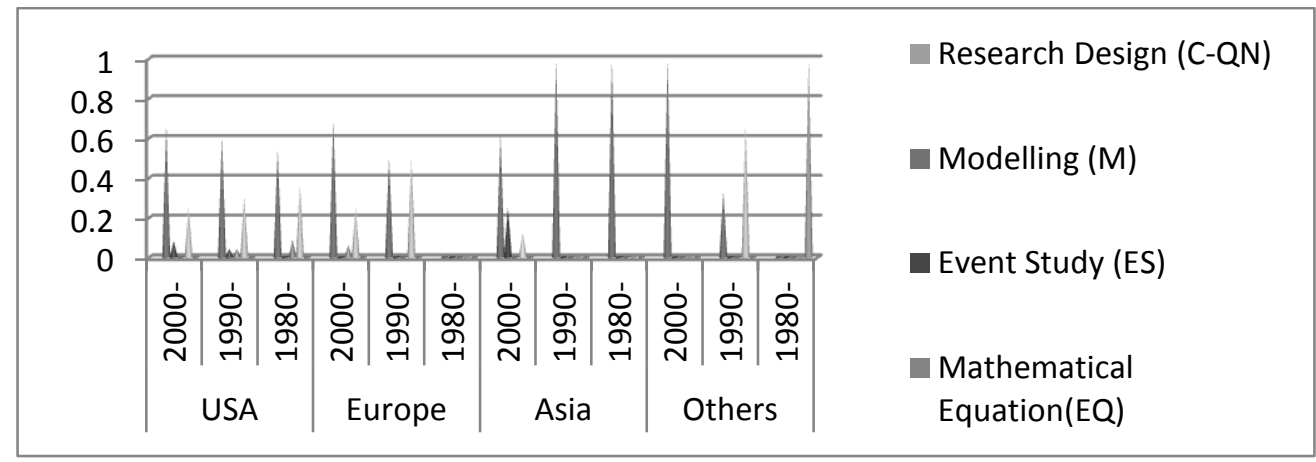

Figure 9: Research Design Region wise over the years

\subsubsection{Type of Statistical Techniques and the Number of their Usage}

As the research design is discussed, another important part of the methodology that goes with it is the statistical technique used. A number of statistical techniques were identified. Regression alone was divided into different types of regressions. If nothing was mentioned it was treated as a normal regression. There is a basic Ordinary Least Square Regression (OLS) and the more advanced Logistic and Probit Regressions. From figure 10. It can be seen that as the trend of using the modeling research design is decreasing over the years so does the use of regression techniques. Very surprisingly, it can be seen that papers in 1980s identified the regression to be OLS regression, while with time they stopped identifying it and so the unidentified regression graph went up.

Another important finding within this methodology is that with time the number of statistical techniques is also increasing (Figure 11). In 1980s more research was based on single tests. In this decade a lot of research has shifted to use of two and even three tests. Obviously, as all areas are becoming more advanced with time, statistical techniques are also advancing and so does their use. Also the greater the number of techniques used, the more reliable the results would be. This is something happening worldwide. In Asia, there is still use of two techniques as compared to USA and Europe where trend has shifted to using three techniques. 
Mehreen et al. / Publication Trends and Methodological Advancements

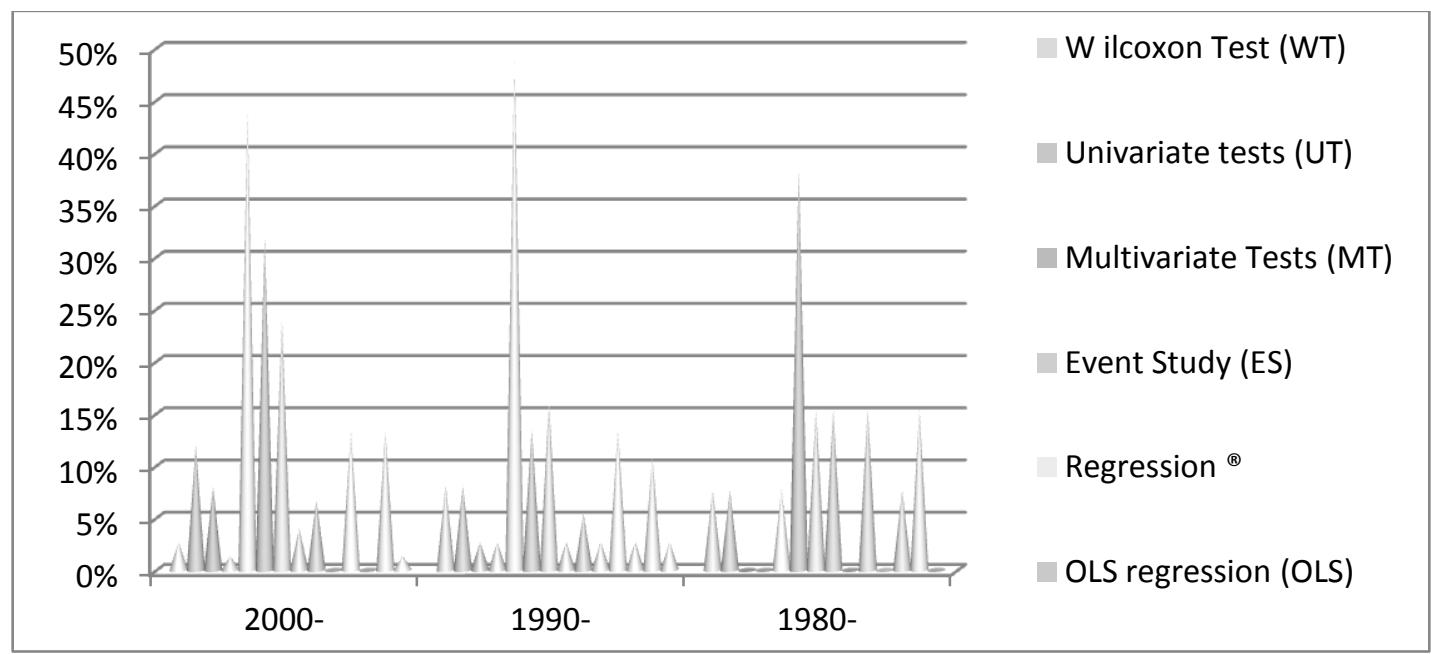

Figure 10: Statistical Techniques over the years

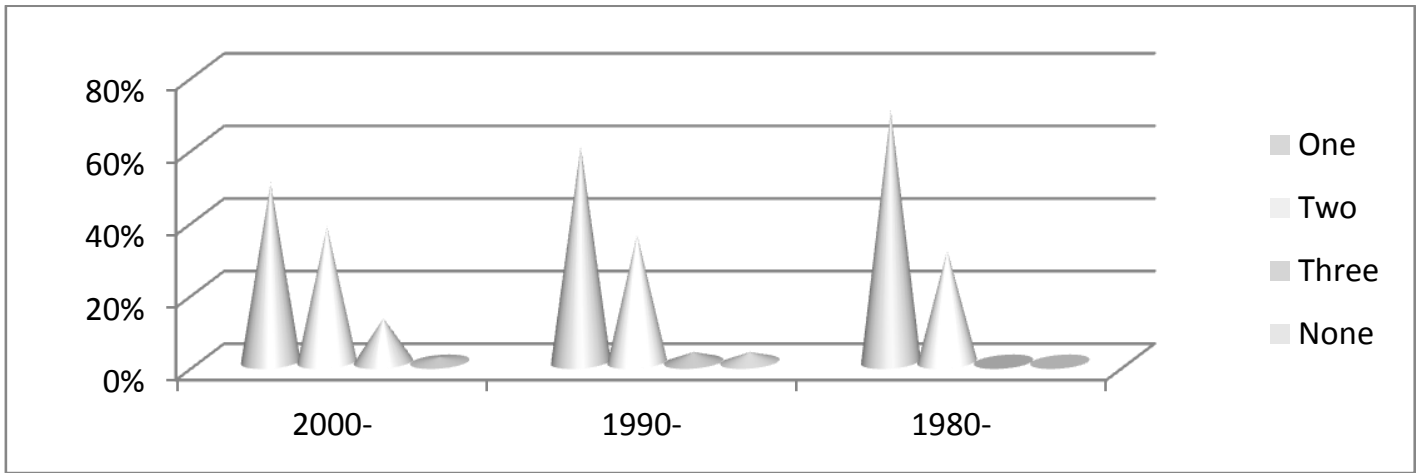

Figure 11a: Number of Statistical Techniques overall over the years and region wise over the years

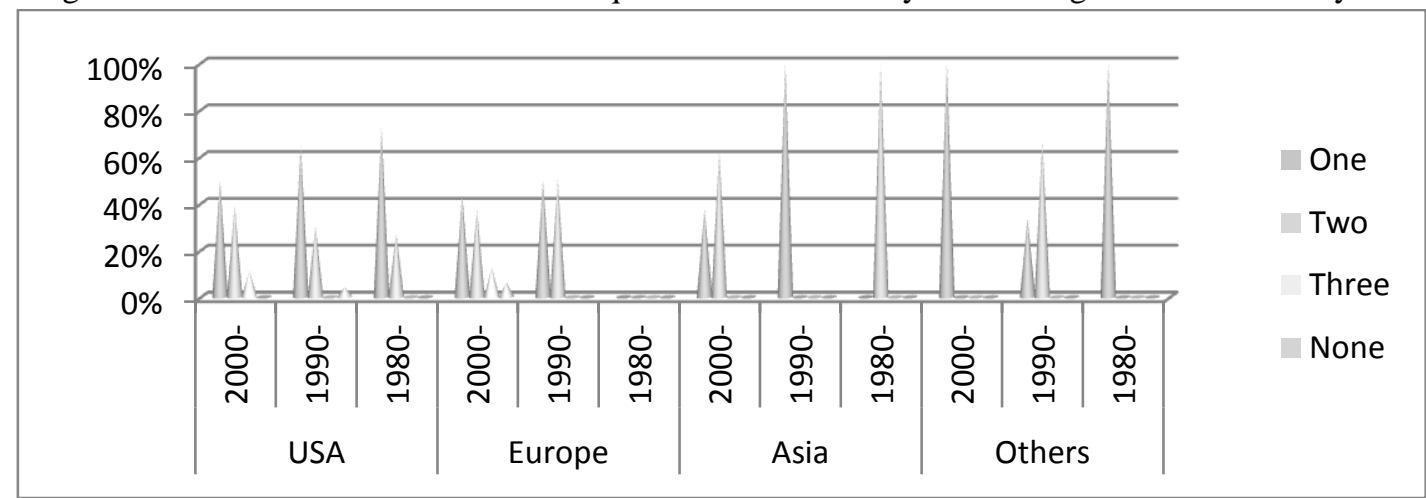

Figure 11b: Number of Statistical Techniques overall over the years and region wise over the years

\subsection{Unit of Analysis}

As explained in the background, Agency cost is most commonly found in corporations. Thus the unit of analysis for research has over the years mainly been Firms. Almost 80\% of research in 2000 were done on firms. Since the characteristic of Financial and Nonfinancial firms are different, they were coded as different units of analysis. As seen from figure 12, the nonfinancial firms are the main unit of analysis over the years. Interestingly, all agency theories were tested in "other" cases more in the 1980s. Others include the field of sports, medicine, real estate and politics. These should have been 
the areas to be explored as time progressed, but the analysis shows that they had been explored previously and now research in them is being done. Financial Firms were explored in 1990s for Agency Cost but now they are being ignored.

Asian research did take into account the agency cost related to the money market in the 1990s, but in the 2000s, even in this area the research shifted to analyzing the non financial firms more.

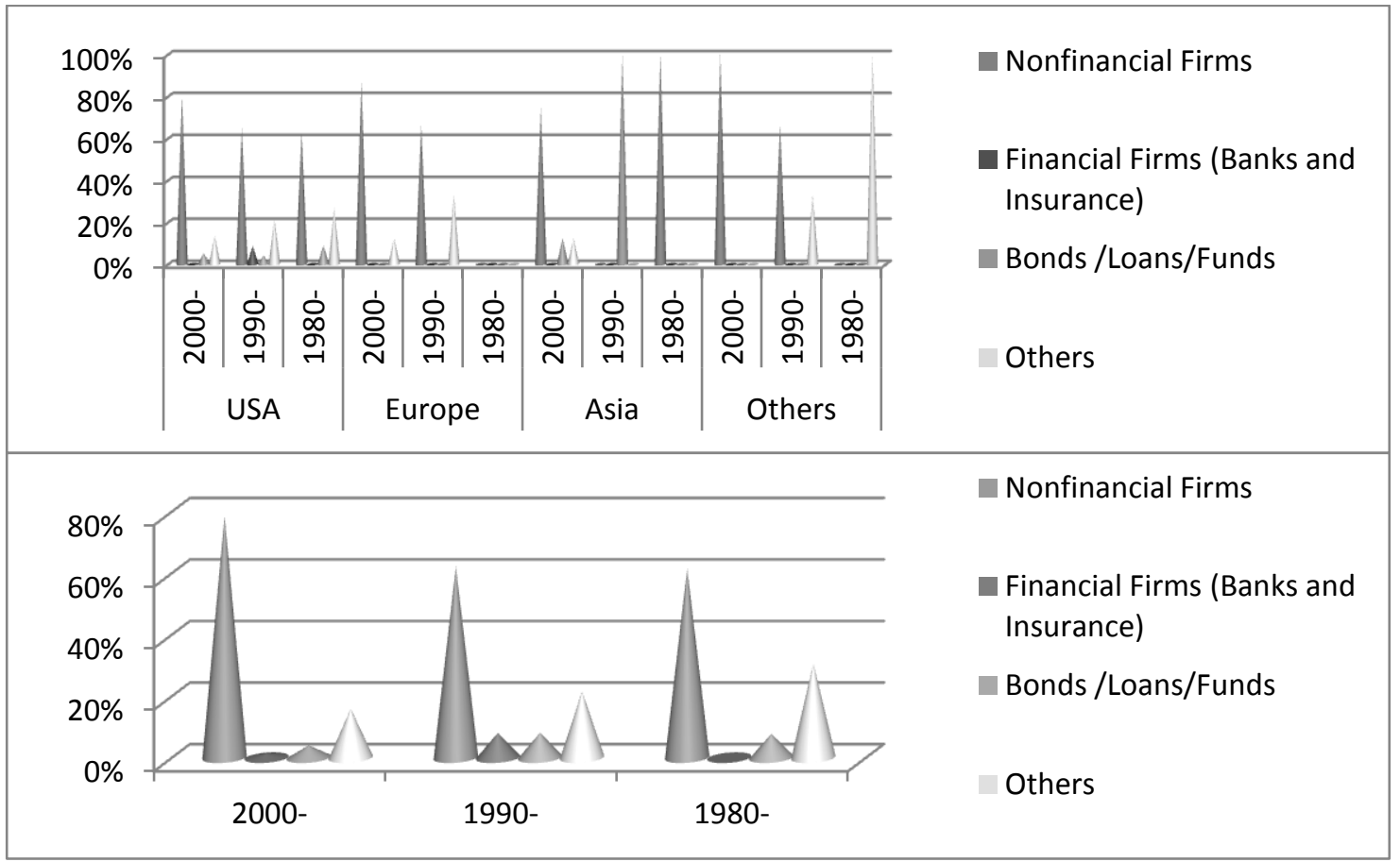

Figure 12a and 12b: Unit of Analysis overall over the years and region wise over the years

\subsection{Type of Data Sources}

Since the research that is being analyzed is all conceptual, the data sources would all be for secondary data. The data sources for this research are divided into data collected from organized databases that are created by different organizations as well as publications by certain departments or research centers. Some of the data was collected from surveys that took place by other sources than the researchers. Also in some cases, government documents or files organized by other agencies, were used. It can be seen (figure 13) that in 1980s publications by some departments were the main source of data. In a very few cases, financial statements by the companies were also used to collect data.

With time though, as more databases are being created and maintained, databases are becoming a common source for secondary data. When the trend is studied regionwise, it can be seen that in USA and Europe, publications are still a greater source of data but in Asia and other countries databases are gaining strength. 
Mehreen et al. / Publication Trends and Methodological Advancements

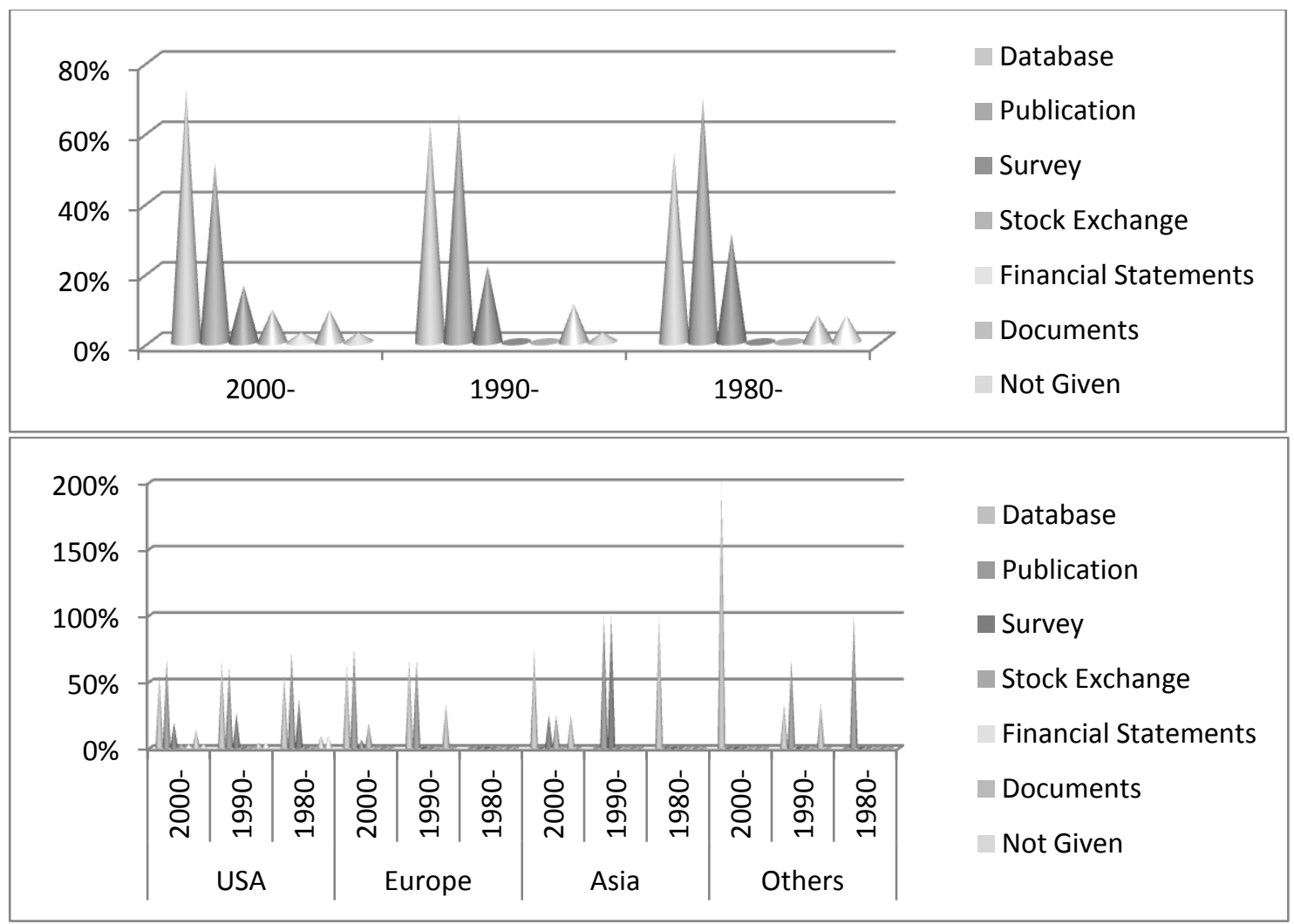

Figure 13a and 13b: Type of Data Sources overall over the years and region wise over the years

The percentage of data sources exceeds $100 \%$ as more than one data source is also used. In most cases the number of data sources used were just one but in some cases other sources are also used to confirm the data or file in the missing data.

\subsection{Time Series}

A very important characteristic of the data in any research is whether the data is longitudinal or cross sectional. It will depend on the type of research design and statistical technique to be used for the analysis. Longitudinal data will be data taken for a set of variables over a number of time periods, with each variable measured for each time period. If a number of variables are measured in one time period, then it will be categorized as cross sectional. Pooled data is a combination of both but is coded so only if the research mentions it. Similarly panel data is a set of variables in different time periods coded only if the research mentions it.

Over the years, it can be seen that the trend is shifting from cross-sectional to longitudinal data. One of the reasons for this could be that as time progresses more longitudinal data is available. Secondly longitudinal data gives better results than cross sectional data for most of the statistical techniques. Yet if the analysis is done region wise, it can be seen that in USA and Europe both cross sectional and longitudinal are preferred, while in Asia the trend has slightly shifted from longitudinal to cross sectional from the 1990 s to 2000 s. 
Mehreen et al. / Publication Trends and Methodological Advancements

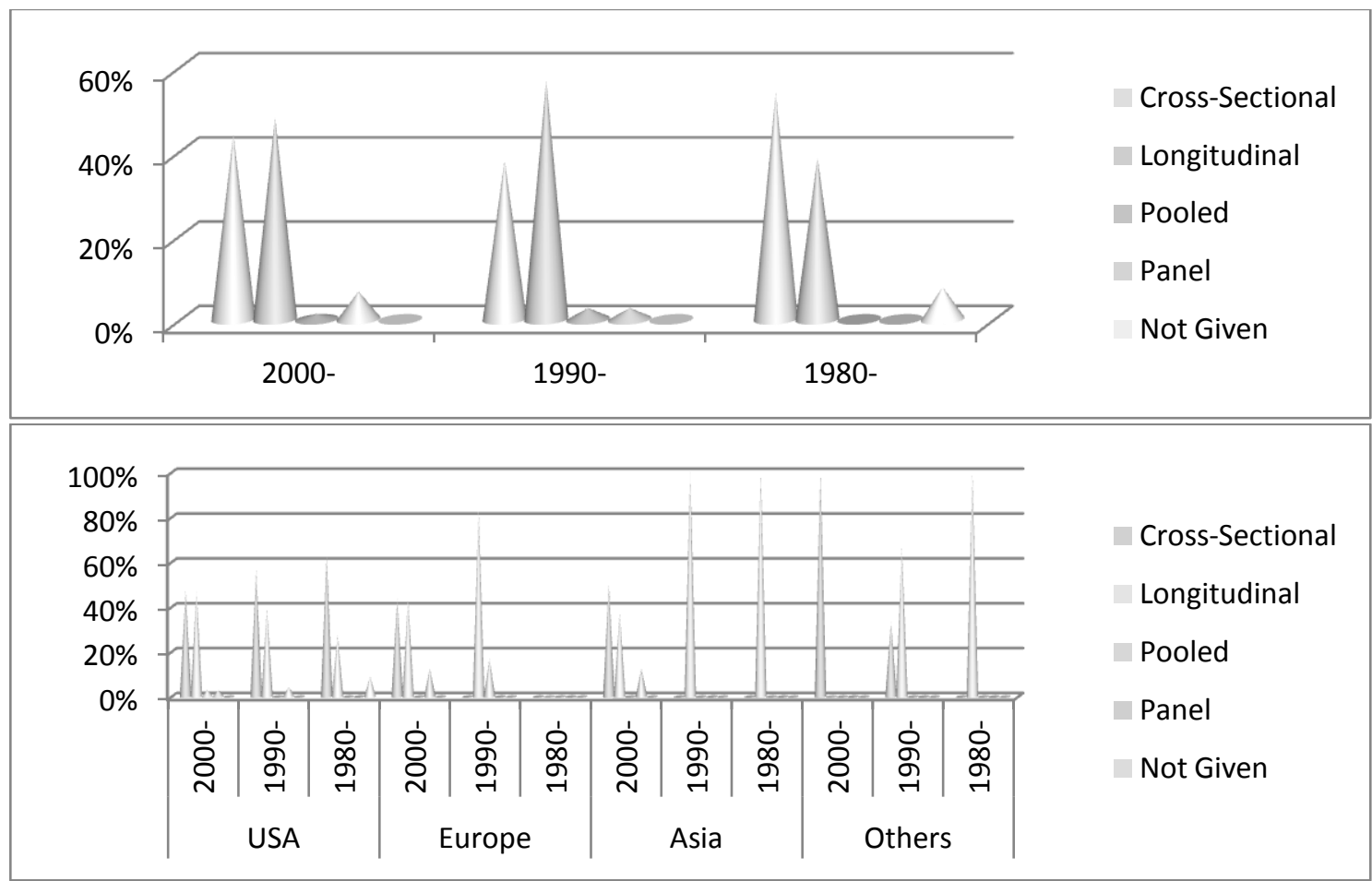

Figure 14a and 14b: Time Series of Data overall over the years and region wise over the years

\subsection{Sample - Time Frame and Region}

\subsubsection{Time Frame of the Sample}

Timely research is always preferred. The more recent the data used in research, the better the research will be considered. Yet, surprisingly, it can be seen (Figure 15) that only about 25\% of the research done in 2000s is on data during that or immediately before that time frame. Rest of the research is divided between data of a decade or more before the actual publication. A possible reason for this could be the time lag between the research done and the publication of the research taking place.

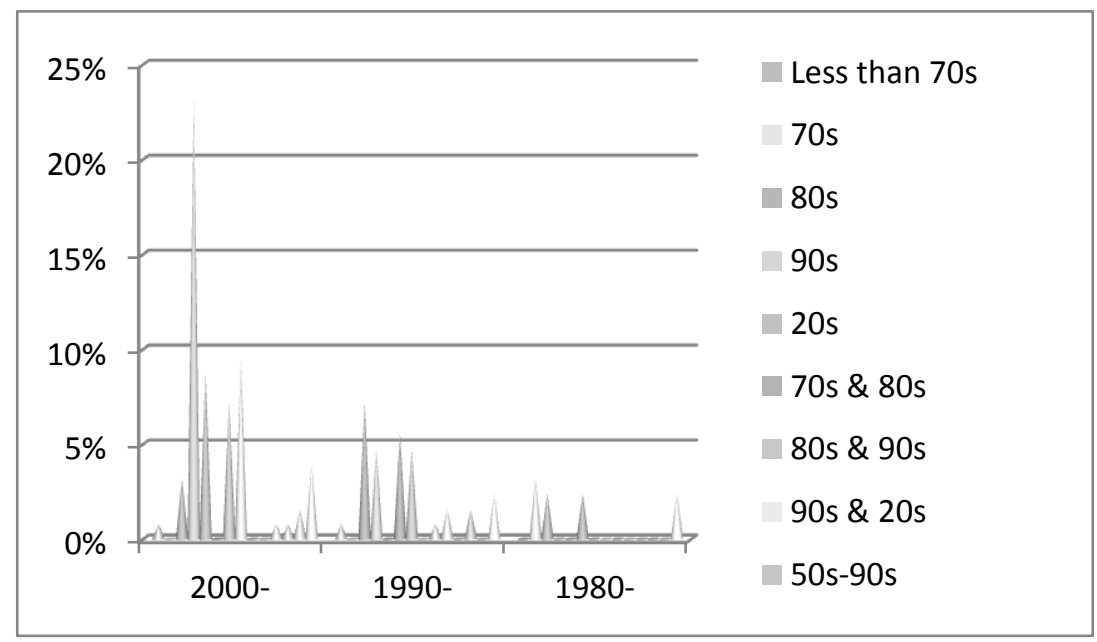

Figure 15: Time Frame of the Sample size over the years 


\subsection{2. $\quad$ Region of Sample Used}

Data for the region in which the research is being done should be more easily available. So it is more convenient to do research on the data of where the research is being done. Also, the research is going to be of more value in the region where it is being done if it is tested in the scenario of that region. It can be seen in figure 16 that all regions are more or less doing major research on the data of the region where the research takes place. It is only in "Others"(Australia and Canada) that major chunk of research in 2000s is on the UK's data. In Asia in 1980s, almost all the research done was on USA's data, but the trend has shifted in 2000 s as they move to their own data. The probable reason for this could probably be that in the 80 s their own data was not developed or available as USAs data is more organized, but with time Asian data is also becoming accessible.

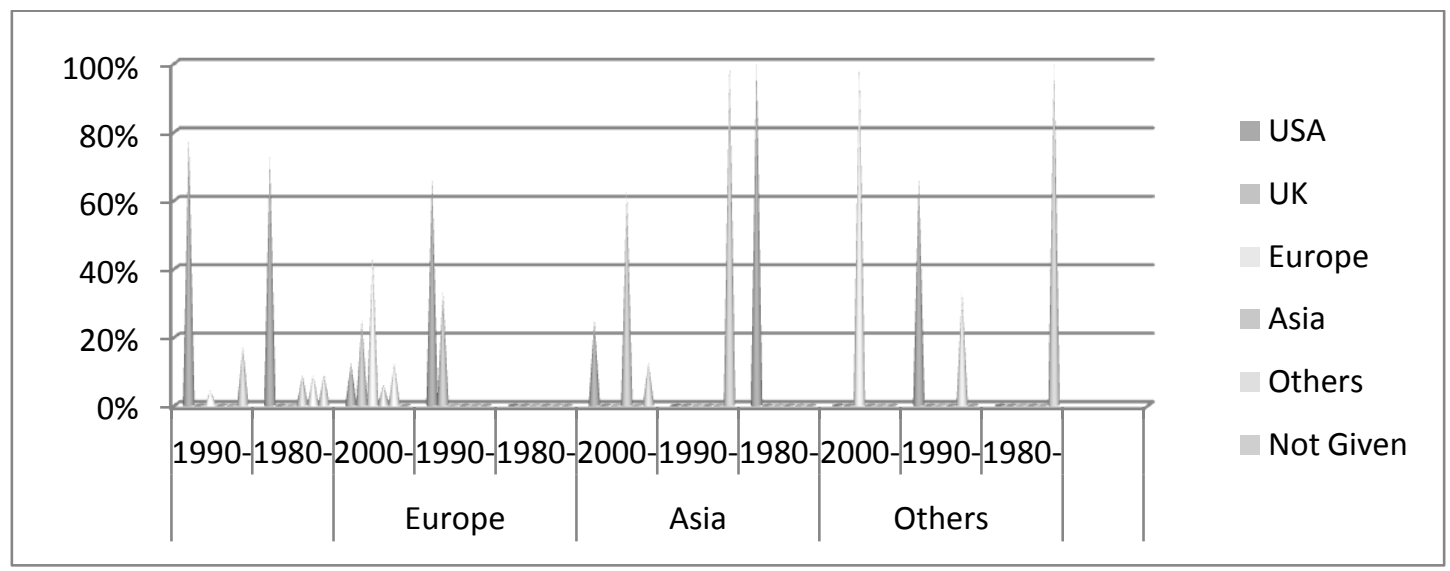

Figure 16: Region of Data region wise over the Years

\section{Discussion and Future Research}

\subsection{Discussion}

The main purpose of this research is to review the literature and study the publication trends and methodological advancements in the area of Agency Cost. For this purpose a sample of conceptual quantitative research is taken into consideration. An analysis is done on it by applying crosstabs on the identified components with years of publication and region of the author to interpret what work is being done where.

It has been found that the major amount of research is being done in USA but Asia is, surprisingly, also not far away. Major research is done by academicians while some practitioners, especially in USA, are also contributing to the research. Major amount of the research is done by single authors and even if there is more than one author, they all belong to a single country. Thus, multiple country authors and collaborations are a very small percentage. Being in Pakistan, a very important result of the analysis shows that a lot of Asian research is being published in good journals with ranking of $\mathrm{A}^{*}$ and A. The major percentage of research in Agency Cost is part of the domain of Economics or Accounting and Finance.

Most of the research being done in the area of Agency Cost is based on the research design using the modeling technique also called the regression analysis. With time, though more than one statistical technique is being used by researchers to justify their results and prove their point. Since the problem 
of Agency Cost occurs mainly in corporations, the unit of analysis in most of the studies is firms, and that too, non-financial firms. The main source of the data is considered to be databases nowadays, as the trend has shifted from publications. Both longitudinal and cross sectional data is prefereble but a general trend shows that in Asia cross sectional is still preferred. One thing that can be concluded is, for good research and for it to be published, the data should preferably be recent (from current or last decade). Also, data of the country where the research is taking place should be considered as it is easily available and will give an accurate picture of what is happening in that region.

\subsection{Limitations and Future Directions in Agency Cost Domain}

This research attempts to do a systematic analysis of literature review in the area of Agency Cost but there is still a lot to be done. Firstly the list of research, on which the analysis is done, is not exhaustive at all. For the purpose of this research only one search engine was taken into consideration. There could be other search engines that should be used to incorporate more research into the sample.

Another limitation of this research is that it analyzes only the conceptual quantitative research. A similar analysis can be done on empirical quantitative and empirical qualitative research as well. That would help give a picture of the overall research that is taking place in this area of Agency Cost.

This research is just a starting point. Its main implications is in the area of academics. A more detailed or useful analysis could be to do a Meta - Analysis of the results of various research done. In that sort of research, a summary of all the research being done in this domain can be concluded, which would have more practical and managerial implications of the results.

Also, an analysis of measurement variables will be helpful. Since most of the research in this area is done through modeling, a lot of variables are involved in estimating the models. An analysis can be done on what are the variables that studies use for agency cost and how are they measured. This would help in evaluating the quality of research and help set guidelines and give helpful tips for future research.

A more detailed analysis that would help us determine the gaps in research could be a Thematic Analysis. Such an analysis will help in determining the various themes being studied in this area and this would make the researcher to be in a better position to be able to judge what work is being done in this domain. Thus, the topics not covered or not explored can be looked into in detail for further research.

Similarly a Citation Analysis can also be done. This is a sort of a continuation of the Publication analysis as it helps analyze how many times articles are being cited and in what sort of research are they being cited in. This would help determine the quality of the articles as well as the journals as more citation or good citation would raise the quality.

\section{Conclusion}

From this research it can be concluded that most of the work being done in the Area of Agency cost is conceptual, using secondary data. Qualitative is more but quantitative is also gaining strength. 
Asia is a region which is showing signs of good quality and more research is taking place in this area with a greater number of researchers and more use of statistical techniques for analysis thus , improving the quantitative strength of the research. 


\section{References}

Adhikari, Ajay, Tondkar, Rasoul H., Hora, Judith A., (2002). An analysis of international accounting research in Journal of International Accounting Auditing \& Taxation: 1992-2001, Journal of International Accounting, Auditing \& Taxation 11, 39-49.

Atkinson, S. E., Stanley, L. R., \& Tschirhart, J. (1988). Revenue sharing as an incentive in an agency problem: An example from the national football league. RAND Journal of Economics (RAND Journal of Economics), 19(1), 27-43.

Bisman, Jayne, (2010). Postpositivism and Accounting Research: A (Personal)Primer on Critical Realism, $A A F B J$, Volume 4, no. 4.

Borkowski, Susan C., Welsh, Mary Jeanne, Wentzel, Kristin,(2012). Sustainability reporting at Johnson \& Johnson: A case study using content analysis, IJBIT/ Volume 4 / Sp Issue 3.

Botha, E., Lilford, N., Pitt, L., (2011). South African management literature over the past fifteen years: Content analysis of the three top South African management journals, South African Journal of Business Management 42 (4).

Brereton, Pearl, Kitchenham, Barbara A., Budgen, David, Turner, Mark, Mohamed, khalil, (2007). Lessons from applying the systematic literature review process with the software engineering domain, The Journal of Systems and Software 80, 571 - 583.

Cohen,Jeffrey R.;Holder-Webb,Lori, (2006). Rethinking the Influence of Agency Theory in the Accounting Academy, Issues in Accounting Education, Vol. 21, No. 1 February 2006 pp. 17-30.

Creswell, John W. (1994). Research Design: Qualitative and Quantitative Approaches. Thousand Oaks, California, Sage Publications, Inc.

Dangayach,G.S., and Deshmukh, S.G., (2001), Manufacturing strategy: experiences from Indian manufacturing companies, Production Planning \& Control, Vol. 12, No. 8.

Fama, E. F., "Agency problems and the Theory of the Firm” Journal of Political Economy, Vol. 88. (1980) 288 - 307. In Ellwood, W. J. and Walsh, P.J., "Mergers Acquisitions, and the Pruning of Managerial Deadwood” Strategic Management Journal, Vol. 12, No. 3. (Mar. 1991), 201 - 217.

Furubotn, E. and Pejovich, S., "Property Rights, Economic Decentralization and the Evolution of the Yugoslav Firm, 1965 - 72" Journal of Law and Economics, Vol. 16 (1973) 175 - 307. In Ellwood, W. J. and Walsh, P.J., "Mergers Acquisitions, and the Pruning of Managerial Deadwood" Strategic Management Journal, Vol. 12, No. 3. (Mar. 1991), 201 - 217.

Gailmard, S., \& Jenkins, J. A. (2009). Agency problems, the 17th amendment, and representation in the senate. American Journal of Political Science, 53(2), 324-342.

Gerhard, Daniel, Brem, Alexander, Baccarella, Christian, Voigt, Kai-Ingo, (2011). Innovation Management and Marketing in the High-Tech Sector: A Content Analysis of Advertisements, International Journal of Management Vol. 28 No. 1 Part 2.

Graff, R. A., \& Webb, J. R. (1997). Agency costs and inefficiency in commercial real estate. Journal of Real Estate Portfolio Management, 3(1), 19-36. 
Hanna, Sherman D., Ji, HoJun, Lee, Jonghee, Son, Jiyeon, Letkiewicz, Jodi, Lim, HanNa, Zhang, Lishu, (2011). Content analysis of Financial Services Review, Financial Services Review 20 (2011) 237-251.

Heath,Joseph, (2009). The Uses and Abuses of Agency Theory, Business Ethics Quarterly, 19:4 (October 2009); ISSN 1052-150X pp. 497-528.

Iizuka, T. (2007). Experts' agency problems: Evidence from the prescription drug market in japan. RAND Journal of Economics (Blackwell Publishing Limited), 38(3), 844-862.

Jensen , K. L. (2005). A basic study of agency-cost source and municipal use of internal versus external control. Accounting \& Business Research, 35(1), 53-67.

Jensen, C. M. and Meckling, W. H.,(1976). " Theory of the Firm: Managerial Behaviour, Agency Costs and Ownership Structure", Journal of Financial Economics, Vol. 3. (1976) 305 - 360. In Ellwood, W. J. and Walsh, P.J., "Mergers Acquisitions, and the Pruning of Managerial Deadwood" Strategic Management Journal, Vol. 12, No. 3. (Mar. 1991), 201 - 217.

Jensen, M. C., Meckling, W. H., (1979). Rights and production functions: An application to labormanaged firms and codetermination, Journal of Business, 52, pp. 469-506 In Ellwood, W. J. and Walsh, P.J., "Mergers Acquisitions, and the Pruning of Managerial Deadwood" Strategic Management Journal, Vol. 12, No. 3. (Mar. 1991), 201 - 217.

Jensen, M.C., Smith C., (1985). Stockholder, manager, and creditor interests: Applications of agency theory In Ellwood, W. J. and Walsh, P.J., "Mergers Acquisitions, and the Pruning of Managerial Deadwood" Strategic Management Journal, Vol. 12, No. 3. (Mar. 1991), 201 - 217.

Leaver, C. (2009). Bureaucratic minimal squawk behavior: Theory and evidence from regulatory agencies. American Economic Review, 99(3), 572-607.

Macdonald,Glenn M., (1984). New directions in the economic theory of agency, Canadian Journal of Economics.

McClure, J. E., \& Spector, L. C. (1997). Tournament performance and 'agency' problems: An empirical investigation of 'march madness'. Journal of Economics \& Finance, 21(1), 61.

McGuire, R. A., \& Ohsfeldt, R. L. (1989). Self-interest, agency theory, and political voting behavior: The ratification of the united states constitution. American Economic Review, 79(1), 219.

Minor III. E., Hensley, R.L., \& Wood Jr., R.D. (1993). A review of empirical manufacturing strategy studies. International Journal of Operations and Production Management, 14(1), 5-25

Nakata, C., \& Huang, Y. (2005). Progress and promise: the last decade of international marketing research. Journal of Business Research, 58, 611-618.

Page, A.L., and Schirr, G.R., (2008), Growth and development of a body of knowledge: 16 years of new product development research, 1989 - 2004, Journal of Product Innovation Management, No. 25, pp 233-248. 
Sutton, Robert I., (1997). The Virtues of Closet Qualitative Reasearch, Organization Science, Vol. 8, No. 1, pp. 97 - 106.

Sutton, Robert I., Staw, Barry M., (1995). What Theory is Not, Administrative Science Quarterly, Vol. 40, No. 3 (Sep., 1995), pp. 371 - 384.

Wu, YEN-CHUN JIM, Huang, Shihping, Kuo, Lopin, Wu, Wen-Hsuing,( 2010). Management Education for Sustainability: A Web-Based Content Analysis, Academy of Management Learning \& Education, 2010, Vol. 9, No. 3, 520-531. 
Mehreen et al. / Publication Trends and Methodological Advancements

\begin{tabular}{|c|c|c|c|c|}
\hline & All Years & $2000-$ & 1990- & 1980- \\
\hline Total Studies & 314 & 163 & 101 & 50 \\
\hline Empirical & $13 \%$ & $12 \%$ & $15 \%$ & $88 \%$ \\
\hline Conceptual & $87 \%$ & $88 \%$ & $85 \%$ & $12 \%$ \\
\hline Empirical Quantitative & $10 \%$ & $10 \%$ & $9 \%$ & $10 \%$ \\
\hline Empirical Qualitative & $3 \%$ & $2 \%$ & $6 \%$ & $2 \%$ \\
\hline Conceptual Qualitative & $47 \%$ & $42 \%$ & $49 \%$ & $62 \%$ \\
\hline Conceptual Quantitative & $40 \%$ & $46 \%$ & $37 \%$ & $26 \%$ \\
\hline \multicolumn{5}{|l|}{ Research Design (C-QN) } \\
\hline Modelling (M) & $64 \%$ & $67 \%$ & $62 \%$ & $54 \%$ \\
\hline Event Study (E) & $6 \%$ & $9 \%$ & $3 \%$ & $0 \%$ \\
\hline Mathematical Equation(EQ) & $2 \%$ & $1 \%$ & $3 \%$ & $8 \%$ \\
\hline Statistical Techniques(S) & $26 \%$ & $21 \%$ & $32 \%$ & $31 \%$ \\
\hline Non Parametric Tests(N) & $2 \%$ & $1 \%$ & $0 \%$ & $8 \%$ \\
\hline \multicolumn{5}{|l|}{ Unit of Analysis } \\
\hline Nonfinancial Firms & $72 \%$ & $79 \%$ & $62 \%$ & $62 \%$ \\
\hline Financial Firms (Banks and Insurance) & $3 \%$ & $1 \%$ & $8 \%$ & $0 \%$ \\
\hline Bonds /Loans/Funds & $6 \%$ & $4 \%$ & $8 \%$ & $8 \%$ \\
\hline Others & $19 \%$ & $16 \%$ & $22 \%$ & $31 \%$ \\
\hline \multicolumn{5}{|l|}{ Data Source } \\
\hline Database & $67 \%$ & $72 \%$ & $62 \%$ & $54 \%$ \\
\hline Publication & $57 \%$ & $51 \%$ & $65 \%$ & $69 \%$ \\
\hline Survey & $19 \%$ & $16 \%$ & $22 \%$ & $31 \%$ \\
\hline Stock Exchange & $6 \%$ & $9 \%$ & $0 \%$ & $0 \%$ \\
\hline Financial Statements & $2 \%$ & $3 \%$ & $0 \%$ & $0 \%$ \\
\hline Documents & $10 \%$ & $9 \%$ & $11 \%$ & $8 \%$ \\
\hline Not Given & $3 \%$ & $3 \%$ & $3 \%$ & $8 \%$ \\
\hline \multicolumn{5}{|l|}{ Number of Sources } \\
\hline One & $53 \%$ & $52 \%$ & $57 \%$ & $46 \%$ \\
\hline Two & $30 \%$ & $31 \%$ & $27 \%$ & $31 \%$ \\
\hline Three & $15 \%$ & $16 \%$ & $14 \%$ & $15 \%$ \\
\hline not given & $2 \%$ & $1 \%$ & $3 \%$ & $8 \%$ \\
\hline \multicolumn{5}{|l|}{ Country of Data } \\
\hline USA & $56 \%$ & $45 \%$ & $73 \%$ & $69 \%$ \\
\hline UK & $6 \%$ & $8 \%$ & $5 \%$ & $0 \%$ \\
\hline France & $11 \%$ & $17 \%$ & $3 \%$ & $0 \%$ \\
\hline Japan & $13 \%$ & $20 \%$ & $0 \%$ & $8 \%$ \\
\hline
\end{tabular}


Mehreen et al. / Publication Trends and Methodological Advancements

\begin{tabular}{|c|c|c|c|c|}
\hline Korea & $0 \%$ & $0 \%$ & $0 \%$ & $0 \%$ \\
\hline Taiwan & $0 \%$ & $0 \%$ & $0 \%$ & $0 \%$ \\
\hline Not Given & $10 \%$ & $5 \%$ & $16 \%$ & $15 \%$ \\
\hline \multicolumn{5}{|l|}{ Decades } \\
\hline Less than $70 \mathrm{~s}$ & $2 \%$ & $1 \%$ & $1 \%$ & $0 \%$ \\
\hline $70 \mathrm{~s}$ & $3 \%$ & $0 \%$ & $0 \%$ & $3 \%$ \\
\hline $80 \mathrm{~s}$ & $13 \%$ & $3 \%$ & $7 \%$ & $2 \%$ \\
\hline $90 \mathrm{~s}$ & $28 \%$ & $23 \%$ & $5 \%$ & $0 \%$ \\
\hline $20 \mathrm{~s}$ & $9 \%$ & $9 \%$ & $0 \%$ & $0 \%$ \\
\hline $70 s \& 80 s$ & $8 \%$ & $0 \%$ & $6 \%$ & $2 \%$ \\
\hline $80 \mathrm{~s} \& 90 \mathrm{~s}$ & $12 \%$ & $7 \%$ & $5 \%$ & $0 \%$ \\
\hline $90 \mathrm{~s} \& 20 \mathrm{~s}$ & $10 \%$ & $10 \%$ & $0 \%$ & $0 \%$ \\
\hline $50 s-90 s$ & $1 \%$ & $0 \%$ & $1 \%$ & $0 \%$ \\
\hline $60 \mathrm{~s}, 70 \mathrm{~s} \& 80 \mathrm{~s}$ & $2 \%$ & $0 \%$ & $2 \%$ & $0 \%$ \\
\hline $70 \mathrm{~s}, 80 \mathrm{~s} \& 90 \mathrm{~s}$ & $1 \%$ & $1 \%$ & $0 \%$ & $0 \%$ \\
\hline $70 \mathrm{~s}, 80 \mathrm{~s}, 90 \mathrm{~s} \& 20 \mathrm{~s}$ & $2 \%$ & $1 \%$ & $2 \%$ & $0 \%$ \\
\hline $80 \mathrm{~s}, 90 \mathrm{~s} \& 20 \mathrm{~s}$ & $2 \%$ & $2 \%$ & $0 \%$ & $0 \%$ \\
\hline Not Given & $9 \%$ & $4 \%$ & $2 \%$ & $2 \%$ \\
\hline \multicolumn{5}{|l|}{ Time Series } \\
\hline Cross-Sectional & $43 \%$ & $44 \%$ & $38 \%$ & $54 \%$ \\
\hline Longitudinal & $50 \%$ & $48 \%$ & $57 \%$ & $38 \%$ \\
\hline Pooled & $2 \%$ & $1 \%$ & $3 \%$ & $0 \%$ \\
\hline Panel & $5 \%$ & $7 \%$ & $3 \%$ & $0 \%$ \\
\hline Not Given & $1 \%$ & $0 \%$ & $0 \%$ & $8 \%$ \\
\hline \multicolumn{5}{|l|}{ Statistical Techniques } \\
\hline W ilcoxon Test (WT) & $5 \%$ & $3 \%$ & $8 \%$ & $8 \%$ \\
\hline Univariate tests (UT) & $10 \%$ & $12 \%$ & $8 \%$ & $8 \%$ \\
\hline Multivariate Tests (MT) & $6 \%$ & $8 \%$ & $3 \%$ & $0 \%$ \\
\hline Event Study (ES) & $2 \%$ & $1 \%$ & $3 \%$ & $0 \%$ \\
\hline Regression ${ }^{\circledR}$ & $42 \%$ & $44 \%$ & $49 \%$ & $8 \%$ \\
\hline OLS regression (OLS) & $27 \%$ & $32 \%$ & $14 \%$ & $38 \%$ \\
\hline Logit Regression (LR) & $21 \%$ & $24 \%$ & $16 \%$ & $15 \%$ \\
\hline probit model (PM) & $5 \%$ & $4 \%$ & $3 \%$ & $15 \%$ \\
\hline linear / non linear specification(MP) & $6 \%$ & $7 \%$ & $5 \%$ & $0 \%$ \\
\hline Maximum likelihood estimation(ML) & $2 \%$ & $0 \%$ & $3 \%$ & $15 \%$ \\
\hline Correlation Analysis@ & $12 \%$ & $13 \%$ & $14 \%$ & $0 \%$ \\
\hline ANOVA & $2 \%$ & $0 \%$ & $3 \%$ & $8 \%$ \\
\hline Others & $13 \%$ & $13 \%$ & $11 \%$ & $15 \%$ \\
\hline No Tests & $2 \%$ & $1 \%$ & $3 \%$ & $0 \%$ \\
\hline No. of Test & & & & \\
\hline
\end{tabular}


Mehreen et al. / Publication Trends and Methodological Advancements

\begin{tabular}{|l|l|l|l|l|}
\hline One & $54 \%$ & $49 \%$ & $59 \%$ & $69 \%$ \\
\hline Two & $36 \%$ & $37 \%$ & $35 \%$ & $31 \%$ \\
\hline Three & $8 \%$ & $12 \%$ & $3 \%$ & $0 \%$ \\
\hline None & $2 \%$ & $1 \%$ & $3 \%$ & $0 \%$ \\
\hline
\end{tabular}

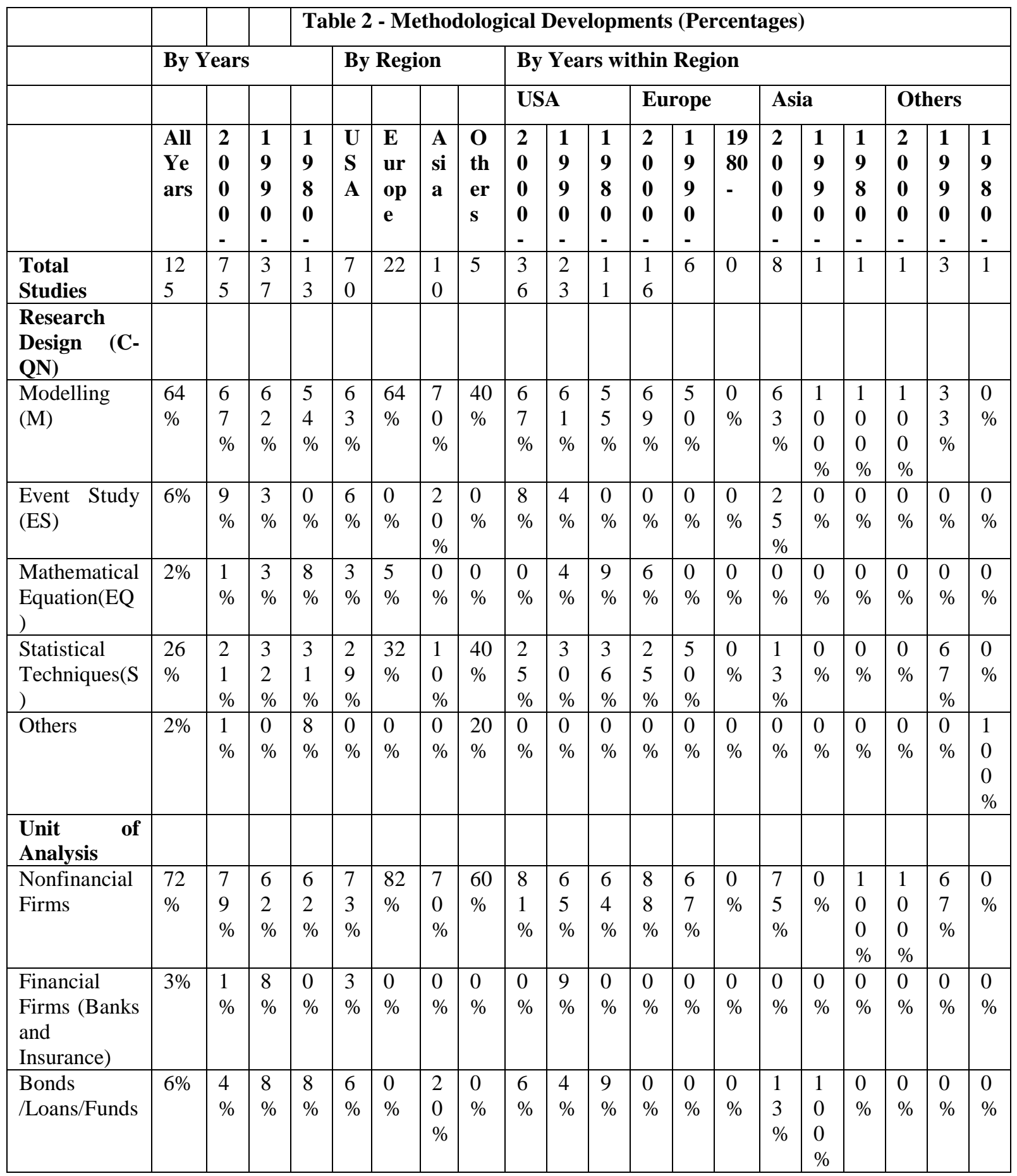


Mehreen et al. / Publication Trends and Methodological Advancements

\begin{tabular}{|c|c|c|c|c|c|c|c|c|c|c|c|c|c|c|c|c|c|c|c|c|}
\hline Others & $\begin{array}{l}19 \\
\%\end{array}$ & $\begin{array}{l}1 \\
6 \\
\%\end{array}$ & $\begin{array}{l}2 \\
2 \\
\%\end{array}$ & $\begin{array}{l}3 \\
1 \\
\%\end{array}$ & $\begin{array}{l}1 \\
9 \\
\%\end{array}$ & $\begin{array}{l}18 \\
\%\end{array}$ & \begin{tabular}{l|}
1 \\
0 \\
$\%$
\end{tabular} & $\begin{array}{l}40 \\
\%\end{array}$ & $\begin{array}{l}1 \\
4 \\
\%\end{array}$ & $\begin{array}{l}2 \\
2 \\
\%\end{array}$ & \begin{tabular}{l|}
2 \\
7 \\
$\%$
\end{tabular} & $\begin{array}{l}1 \\
3 \\
\%\end{array}$ & $\begin{array}{l}3 \\
3 \\
\%\end{array}$ & $\begin{array}{l}0 \\
\%\end{array}$ & $\begin{array}{l}1 \\
3 \\
\%\end{array}$ & $\begin{array}{l}0 \\
\%\end{array}$ & \begin{tabular}{l|}
0 \\
$\%$
\end{tabular} & $\begin{array}{l}0 \\
\%\end{array}$ & $\begin{array}{l}3 \\
3 \\
\%\end{array}$ & $\begin{array}{l}1 \\
0 \\
0 \\
\%\end{array}$ \\
\hline \multicolumn{21}{|l|}{ Data Source } \\
\hline Database & $\begin{array}{l}67 \\
\%\end{array}$ & $\begin{array}{l}7 \\
2 \\
\%\end{array}$ & $\begin{array}{l}6 \\
2 \\
\%\end{array}$ & $\begin{array}{l}5 \\
4 \\
\%\end{array}$ & $\begin{array}{l}5 \\
9 \\
\%\end{array}$ & $\begin{array}{l}64 \\
\%\end{array}$ & $\begin{array}{l}7 \\
0 \\
\%\end{array}$ & $\begin{array}{l}60 \\
\%\end{array}$ & $\begin{array}{l}5 \\
6 \\
\%\end{array}$ & $\begin{array}{l}6 \\
5 \\
\%\end{array}$ & $\begin{array}{l}5 \\
5 \\
\%\end{array}$ & $\begin{array}{l}6 \\
3 \\
\%\end{array}$ & $\begin{array}{l}6 \\
7 \\
\%\end{array}$ & $\begin{array}{l}0 \\
\%\end{array}$ & $\begin{array}{l}7 \\
5 \\
\%\end{array}$ & $\begin{array}{l}0 \\
\%\end{array}$ & $\begin{array}{l}1 \\
0 \\
0 \\
\%\end{array}$ & $\begin{array}{l}2 \\
0 \\
0 \\
\%\end{array}$ & $\begin{array}{l}3 \\
3 \\
\%\end{array}$ & $\begin{array}{l}0 \\
\%\end{array}$ \\
\hline Publication & $\begin{array}{l}57 \\
\%\end{array}$ & $\begin{array}{l}5 \\
1 \\
\%\end{array}$ & $\begin{array}{l}6 \\
5 \\
\%\end{array}$ & $\begin{array}{l}6 \\
9 \\
\%\end{array}$ & $\begin{array}{l}6 \\
6 \\
\%\end{array}$ & $\begin{array}{l}73 \\
\%\end{array}$ & $\begin{array}{l}1 \\
0 \\
\%\end{array}$ & $\begin{array}{l}60 \\
\%\end{array}$ & $\begin{array}{l}6 \\
7 \\
\%\end{array}$ & $\begin{array}{l}6 \\
1 \\
\%\end{array}$ & \begin{tabular}{l|}
7 \\
3 \\
$\%$
\end{tabular} & $\begin{array}{l}7 \\
5 \\
\%\end{array}$ & $\begin{array}{l}6 \\
7 \\
\%\end{array}$ & $\begin{array}{l}0 \\
\%\end{array}$ & $\begin{array}{l}0 \\
\%\end{array}$ & $\begin{array}{l}1 \\
0 \\
0 \\
\% \\
\end{array}$ & $\begin{array}{l}0 \\
\%\end{array}$ & $\begin{array}{l}0 \\
\%\end{array}$ & $\begin{array}{l}6 \\
7 \\
\%\end{array}$ & $\begin{array}{l}1 \\
0 \\
0 \\
\%\end{array}$ \\
\hline Survey & $\begin{array}{l}19 \\
\%\end{array}$ & $\begin{array}{l}1 \\
6 \\
\%\end{array}$ & $\begin{array}{l}2 \\
2 \\
\%\end{array}$ & $\begin{array}{l}3 \\
1 \\
\%\end{array}$ & $\begin{array}{l}2 \\
4 \\
\%\end{array}$ & $\begin{array}{l}5 \\
\%\end{array}$ & \begin{tabular}{l|}
3 \\
0 \\
$\%$
\end{tabular} & $\begin{array}{l}0 \\
\%\end{array}$ & $\begin{array}{l}1 \\
9 \\
\%\end{array}$ & $\begin{array}{l}2 \\
6 \\
\%\end{array}$ & $\begin{array}{l}3 \\
6 \\
\%\end{array}$ & $\begin{array}{l}6 \\
\%\end{array}$ & $\begin{array}{l}0 \\
\%\end{array}$ & $\begin{array}{l}0 \\
\%\end{array}$ & $\begin{array}{l}2 \\
5 \\
\%\end{array}$ & $\begin{array}{l}1 \\
0 \\
0 \\
\%\end{array}$ & $\begin{array}{l}0 \\
\%\end{array}$ & $\begin{array}{l}0 \\
\%\end{array}$ & $\begin{array}{l}0 \\
\%\end{array}$ & $\begin{array}{l}0 \\
\%\end{array}$ \\
\hline $\begin{array}{l}\text { Stock } \\
\text { Exchange }\end{array}$ & $6 \%$ & $\begin{array}{l}9 \\
\%\end{array}$ & $\begin{array}{l}0 \\
\%\end{array}$ & $\begin{array}{l}0 \\
\%\end{array}$ & $\begin{array}{l}1 \\
\%\end{array}$ & $\begin{array}{l}14 \\
\%\end{array}$ & \begin{tabular}{l|}
2 \\
0 \\
$\%$ \\
\end{tabular} & $\begin{array}{l}0 \\
\%\end{array}$ & $\begin{array}{l}3 \\
\%\end{array}$ & $\begin{array}{l}0 \\
\%\end{array}$ & $\begin{array}{l}0 \\
\%\end{array}$ & $\begin{array}{l}1 \\
9 \\
\% \\
\end{array}$ & $\begin{array}{l}0 \\
\%\end{array}$ & $\begin{array}{l}0 \\
\%\end{array}$ & $\begin{array}{l}2 \\
5 \\
\% \\
\end{array}$ & $\begin{array}{l}0 \\
\%\end{array}$ & $\begin{array}{l}0 \\
\%\end{array}$ & $\begin{array}{l}0 \\
\%\end{array}$ & $\begin{array}{l}0 \\
\%\end{array}$ & $\begin{array}{l}0 \\
\%\end{array}$ \\
\hline $\begin{array}{l}\text { Financial } \\
\text { Statements }\end{array}$ & $2 \%$ & $\begin{array}{l}3 \\
\% \\
\end{array}$ & $\begin{array}{l}0 \\
\% \\
\end{array}$ & $\begin{array}{l}0 \\
\%\end{array}$ & $\begin{array}{l}1 \\
\%\end{array}$ & $\begin{array}{l}0 \\
\% \\
\end{array}$ & $\begin{array}{l}0 \\
\% \\
\end{array}$ & $\begin{array}{l}0 \\
\% \\
\end{array}$ & $\begin{array}{l}3 \\
\% \\
\end{array}$ & $\begin{array}{l}0 \\
\% \\
\end{array}$ & $\begin{array}{l}0 \\
\% \\
\end{array}$ & $\begin{array}{l}0 \\
\% \\
\end{array}$ & $\begin{array}{l}0 \\
\% \\
\end{array}$ & $\begin{array}{l}0 \\
\% \\
\end{array}$ & $\begin{array}{l}0 \\
\% \\
\end{array}$ & $\begin{array}{l}0 \\
\% \\
\end{array}$ & $\begin{array}{l}0 \\
\% \\
\end{array}$ & $\begin{array}{l}0 \\
\% \\
\end{array}$ & $\begin{array}{l}0 \\
\% \\
\end{array}$ & $\begin{array}{l}0 \\
\% \\
\end{array}$ \\
\hline Documents & $\begin{array}{l}10 \\
\%\end{array}$ & $\begin{array}{l}9 \\
\%\end{array}$ & $\begin{array}{l}1 \\
1 \\
\% \\
\end{array}$ & $\begin{array}{l}8 \\
\%\end{array}$ & $\begin{array}{l}1 \\
0 \\
\% \\
\end{array}$ & $\begin{array}{l}9 \\
\%\end{array}$ & \begin{tabular}{l|}
2 \\
0 \\
$\%$ \\
\end{tabular} & $\begin{array}{l}20 \\
\%\end{array}$ & $\begin{array}{l}1 \\
4 \\
\% \\
\end{array}$ & $\begin{array}{l}4 \\
\%\end{array}$ & $\begin{array}{l}9 \\
\%\end{array}$ & $\begin{array}{l}0 \\
\%\end{array}$ & $\begin{array}{l}3 \\
3 \\
\% \\
\end{array}$ & $\begin{array}{l}0 \\
\%\end{array}$ & $\begin{array}{l}2 \\
5 \\
\% \\
\end{array}$ & $\begin{array}{l}0 \\
\%\end{array}$ & $\begin{array}{l}0 \\
\%\end{array}$ & $\begin{array}{l}0 \\
\%\end{array}$ & $\begin{array}{l}3 \\
3 \\
\% \\
\end{array}$ & $\begin{array}{l}0 \\
\%\end{array}$ \\
\hline Not Given & $3 \%$ & $\begin{array}{l}3 \\
\%\end{array}$ & $\begin{array}{l}3 \\
\% \\
\end{array}$ & $\begin{array}{l}8 \\
\%\end{array}$ & $\begin{array}{l}4 \\
\% \\
\end{array}$ & $\begin{array}{l}0 \\
\%\end{array}$ & $\begin{array}{l}0 \\
\%\end{array}$ & $\begin{array}{l}0 \\
\%\end{array}$ & $\begin{array}{l}3 \\
\%\end{array}$ & $\begin{array}{l}4 \\
\%\end{array}$ & $\begin{array}{l}9 \\
\%\end{array}$ & $\begin{array}{l}0 \\
\% \\
\end{array}$ & $\begin{array}{l}0 \\
\%\end{array}$ & $\begin{array}{l}0 \\
\%\end{array}$ & $\begin{array}{l}0 \\
\%\end{array}$ & $\begin{array}{l}0 \\
\%\end{array}$ & $\begin{array}{l}0 \\
\% \\
\end{array}$ & $\begin{array}{l}0 \\
\%\end{array}$ & $\begin{array}{l}0 \\
\%\end{array}$ & $\begin{array}{l}0 \\
\%\end{array}$ \\
\hline \multicolumn{21}{|l|}{$\begin{array}{l}\text { Number of } \\
\text { Sources }\end{array}$} \\
\hline One & $\begin{array}{l}53 \\
\%\end{array}$ & $\begin{array}{l}5 \\
2 \\
\%\end{array}$ & $\begin{array}{l}5 \\
7 \\
\%\end{array}$ & $\begin{array}{l}4 \\
6 \\
\%\end{array}$ & $\begin{array}{l}5 \\
0 \\
\%\end{array}$ & $\begin{array}{l}55 \\
\%\end{array}$ & $\begin{array}{l}6 \\
0 \\
\%\end{array}$ & $\begin{array}{l}60 \\
\%\end{array}$ & $\begin{array}{l}5 \\
0 \\
\%\end{array}$ & $\begin{array}{l}5 \\
7 \\
\%\end{array}$ & $\begin{array}{l}3 \\
6 \\
\%\end{array}$ & $\begin{array}{l}5 \\
0 \\
\%\end{array}$ & $\begin{array}{l}6 \\
7 \\
\%\end{array}$ & $\begin{array}{l}19 \\
00 \\
\%\end{array}$ & $\begin{array}{l}6 \\
3 \\
\%\end{array}$ & $\begin{array}{l}0 \\
\%\end{array}$ & $\begin{array}{l}1 \\
0 \\
0 \\
\%\end{array}$ & $\begin{array}{l}0 \\
\%\end{array}$ & $\begin{array}{l}6 \\
7 \\
\%\end{array}$ & $\begin{array}{l}1 \\
0 \\
0 \\
\%\end{array}$ \\
\hline Two & $\begin{array}{l}30 \\
\%\end{array}$ & $\begin{array}{l}3 \\
1 \\
\%\end{array}$ & $\begin{array}{l}2 \\
7 \\
\%\end{array}$ & $\begin{array}{l}3 \\
1 \\
\%\end{array}$ & $\begin{array}{l}3 \\
3 \\
\%\end{array}$ & $\begin{array}{l}32 \\
\%\end{array}$ & $\begin{array}{l}3 \\
0 \\
\%\end{array}$ & $\begin{array}{l}40 \\
\%\end{array}$ & $\begin{array}{l}3 \\
6 \\
\%\end{array}$ & $\begin{array}{l}2 \\
6 \\
\%\end{array}$ & $\begin{array}{l}3 \\
6 \\
\%\end{array}$ & $\begin{array}{l}3 \\
8 \\
\%\end{array}$ & $\begin{array}{l}1 \\
7 \\
\%\end{array}$ & $\begin{array}{l}20 \\
00 \\
\%\end{array}$ & $\begin{array}{l}2 \\
5 \\
\%\end{array}$ & $\begin{array}{l}1 \\
0 \\
0 \\
\% \\
\end{array}$ & $\begin{array}{l}0 \\
\%\end{array}$ & $\begin{array}{l}1 \\
0 \\
0 \\
\%\end{array}$ & $\begin{array}{l}3 \\
3 \\
\%\end{array}$ & $\begin{array}{l}0 \\
\%\end{array}$ \\
\hline Three & $\begin{array}{l}15 \\
\%\end{array}$ & $\begin{array}{l}1 \\
6 \\
\% \\
\end{array}$ & $\begin{array}{l}1 \\
4 \\
\%\end{array}$ & $\begin{array}{l}1 \\
5 \\
\% \\
\end{array}$ & $\begin{array}{l}1 \\
4 \\
\% \\
\end{array}$ & $\begin{array}{l}14 \\
\%\end{array}$ & $\begin{array}{l}1 \\
0 \\
\% \\
\end{array}$ & $\begin{array}{l}0 \\
\%\end{array}$ & $\begin{array}{l}1 \\
4 \\
\% \\
\end{array}$ & $\begin{array}{l}1 \\
3 \\
\%\end{array}$ & $\begin{array}{l}1 \\
8 \\
\% \\
\end{array}$ & $\begin{array}{l}1 \\
3 \\
\%\end{array}$ & $\begin{array}{l}1 \\
7 \\
\% \\
\end{array}$ & $\begin{array}{l}21 \\
00 \\
\%\end{array}$ & $\begin{array}{l}1 \\
3 \\
\%\end{array}$ & $\begin{array}{l}0 \\
\%\end{array}$ & $\begin{array}{l}0 \\
\%\end{array}$ & $\begin{array}{l}0 \\
\%\end{array}$ & $\begin{array}{l}0 \\
\%\end{array}$ & $\begin{array}{l}0 \\
\%\end{array}$ \\
\hline Not Given & $2 \%$ & $\begin{array}{l}1 \\
\%\end{array}$ & $\begin{array}{l}3 \\
\%\end{array}$ & $\begin{array}{l}8 \\
\%\end{array}$ & $\begin{array}{l}3 \\
\%\end{array}$ & $\begin{array}{l}0 \\
\%\end{array}$ & $\begin{array}{l}0 \\
\%\end{array}$ & $\begin{array}{l}0 \\
\%\end{array}$ & $\begin{array}{l}0 \\
\%\end{array}$ & $\begin{array}{l}4 \\
\%\end{array}$ & $\begin{array}{l}9 \\
\%\end{array}$ & $\begin{array}{l}0 \\
\%\end{array}$ & $\begin{array}{l}0 \\
\%\end{array}$ & $\begin{array}{l}22 \\
00 \\
\% \\
\end{array}$ & $\begin{array}{l}0 \\
\%\end{array}$ & $\begin{array}{l}0 \\
\%\end{array}$ & $\begin{array}{l}0 \\
\%\end{array}$ & $\begin{array}{l}0 \\
\%\end{array}$ & $\begin{array}{l}0 \\
\%\end{array}$ & $\begin{array}{l}0 \\
\%\end{array}$ \\
\hline \multicolumn{21}{|l|}{$\begin{array}{l}\text { Country of } \\
\text { Data }\end{array}$} \\
\hline USA & $\begin{array}{l}56 \\
\%\end{array}$ & $\begin{array}{l}4 \\
5 \\
\%\end{array}$ & $\begin{array}{l}7 \\
3 \\
\%\end{array}$ & $\begin{array}{l}6 \\
9 \\
\%\end{array}$ & $\begin{array}{l}7 \\
4 \\
\%\end{array}$ & $\begin{array}{l}27 \\
\%\end{array}$ & $\begin{array}{l}3 \\
0 \\
\%\end{array}$ & $\begin{array}{l}40 \\
\%\end{array}$ & $\begin{array}{l}7 \\
2 \\
\%\end{array}$ & $\begin{array}{l}7 \\
8 \\
\%\end{array}$ & $\begin{array}{l}7 \\
3 \\
\%\end{array}$ & $\begin{array}{l}1 \\
3 \\
\%\end{array}$ & $\begin{array}{l}6 \\
7 \\
\%\end{array}$ & $\begin{array}{l}0 \\
\%\end{array}$ & $\begin{array}{l}2 \\
5 \\
\%\end{array}$ & $\begin{array}{l}0 \\
\%\end{array}$ & $\begin{array}{l}1 \\
0 \\
0 \\
\%\end{array}$ & $\begin{array}{l}0 \\
\%\end{array}$ & $\begin{array}{l}6 \\
7 \\
\%\end{array}$ & $\begin{array}{l}0 \\
\%\end{array}$ \\
\hline $\begin{array}{l}\text { UK } \\
\end{array}$ & $6 \%$ & $\begin{array}{l}8 \\
\%\end{array}$ & $\begin{array}{l}5 \\
\%\end{array}$ & $\begin{array}{l}0 \\
\%\end{array}$ & $\begin{array}{l}1 \\
\%\end{array}$ & $\begin{array}{l}27 \\
\%\end{array}$ & $\begin{array}{l}0 \\
\%\end{array}$ & $\begin{array}{l}0 \\
\%\end{array}$ & $\begin{array}{l}3 \\
\%\end{array}$ & $\begin{array}{l}0 \\
\%\end{array}$ & $\begin{array}{l}0 \\
\%\end{array}$ & $\begin{array}{l}2 \\
5 \\
\% \\
\end{array}$ & $\begin{array}{l}3 \\
3 \\
\% \\
\end{array}$ & $\begin{array}{l}0 \\
\%\end{array}$ & $\begin{array}{l}0 \\
\%\end{array}$ & $\begin{array}{l}0 \\
\%\end{array}$ & \begin{tabular}{l|}
0 \\
$\%$
\end{tabular} & $\begin{array}{l}0 \\
\%\end{array}$ & $\begin{array}{l}0 \\
\%\end{array}$ & $\begin{array}{l}0 \\
\%\end{array}$ \\
\hline Europe & 11 & 1 & 3 & 0 & 6 & 32 & 0 & 20 & 8 & 4 & 0 & 4 & 0 & 0 & 0 & 0 & 0 & 1 & 0 & 0 \\
\hline
\end{tabular}


Mehreen et al. / Publication Trends and Methodological Advancements

\begin{tabular}{|c|c|c|c|c|c|c|c|c|c|c|c|c|c|c|c|c|c|c|c|c|}
\hline & $\%$ & $\begin{array}{l}7 \\
\%\end{array}$ & $\%$ & $\%$ & $\%$ & $\%$ & $\%$ & $\%$ & $\%$ & $\%$ & $\%$ & $\begin{array}{l}4 \\
\%\end{array}$ & $\%$ & $\%$ & $\%$ & $\%$ & $\%$ & $\begin{array}{l}0 \\
0 \\
\%\end{array}$ & $\%$ & $\%$ \\
\hline Asia & $\begin{array}{l}13 \\
\%\end{array}$ & $\begin{array}{l}2 \\
0 \\
\%\end{array}$ & $\begin{array}{l}0 \\
\%\end{array}$ & $\begin{array}{l}8 \\
\%\end{array}$ & \begin{tabular}{l|}
6 \\
$\%$
\end{tabular} & $\begin{array}{l}5 \\
\%\end{array}$ & $\begin{array}{l}5 \\
0 \\
\% \\
\end{array}$ & $\begin{array}{l}0 \\
\%\end{array}$ & $\begin{array}{l}8 \\
\%\end{array}$ & $\begin{array}{l}0 \\
\%\end{array}$ & $\begin{array}{l}9 \\
\%\end{array}$ & $\begin{array}{l}6 \\
\%\end{array}$ & $\begin{array}{l}0 \\
\%\end{array}$ & $\begin{array}{l}0 \\
\%\end{array}$ & $\begin{array}{l}6 \\
3 \\
\%\end{array}$ & $\begin{array}{l}0 \\
\%\end{array}$ & $\begin{array}{l}0 \\
\%\end{array}$ & $\begin{array}{l}0 \\
\%\end{array}$ & $\begin{array}{l}0 \\
\%\end{array}$ & $\begin{array}{l}0 \\
\%\end{array}$ \\
\hline Others & $4 \%$ & $\begin{array}{l}4 \\
\%\end{array}$ & \begin{tabular}{l|}
3 \\
$\%$
\end{tabular} & $\begin{array}{l}8 \\
\%\end{array}$ & \begin{tabular}{l|}
3 \\
$\%$
\end{tabular} & $\begin{array}{l}9 \\
\%\end{array}$ & $\begin{array}{l}0 \\
\%\end{array}$ & $\begin{array}{l}20 \\
\%\end{array}$ & $\begin{array}{l}3 \\
\%\end{array}$ & $\begin{array}{l}0 \\
\%\end{array}$ & $\begin{array}{l}9 \\
\%\end{array}$ & $\begin{array}{l}1 \\
3 \\
\% \\
\end{array}$ & $\begin{array}{l}0 \\
\%\end{array}$ & $\begin{array}{l}0 \\
\%\end{array}$ & $\begin{array}{l}0 \\
\%\end{array}$ & $\begin{array}{l}0 \\
\%\end{array}$ & $\begin{array}{l}0 \\
\%\end{array}$ & $\begin{array}{l}0 \\
\%\end{array}$ & $\begin{array}{l}3 \\
3 \\
\% \\
\end{array}$ & $\begin{array}{l}0 \\
\%\end{array}$ \\
\hline Not Given & $\begin{array}{l}10 \\
\%\end{array}$ & $\begin{array}{l}5 \\
\%\end{array}$ & $\begin{array}{l}1 \\
6 \\
\%\end{array}$ & $\begin{array}{l}1 \\
5 \\
\%\end{array}$ & $\begin{array}{l}1 \\
0 \\
\%\end{array}$ & $\begin{array}{l}0 \\
\%\end{array}$ & $\begin{array}{l}2 \\
0 \\
\%\end{array}$ & $\begin{array}{l}20 \\
\%\end{array}$ & $\begin{array}{l}6 \\
\%\end{array}$ & $\begin{array}{l}1 \\
7 \\
\%\end{array}$ & $\begin{array}{l}9 \\
\%\end{array}$ & $\begin{array}{l}0 \\
\%\end{array}$ & $\begin{array}{l}0 \\
\%\end{array}$ & $\begin{array}{l}0 \\
\%\end{array}$ & $\begin{array}{l}1 \\
3 \\
\%\end{array}$ & $\begin{array}{l}1 \\
0 \\
0 \\
\%\end{array}$ & $\begin{array}{l}0 \\
\%\end{array}$ & $\begin{array}{l}0 \\
\%\end{array}$ & $\begin{array}{l}0 \\
\%\end{array}$ & $\begin{array}{l}1 \\
0 \\
0 \\
\%\end{array}$ \\
\hline Decades & & & & & & & & & & & & & & & & & & & & \\
\hline Less than $70 \mathrm{~s}$ & $2 \%$ & $\begin{array}{l}1 \\
\%\end{array}$ & $\begin{array}{l}3 \\
\%\end{array}$ & $\begin{array}{l}0 \\
\%\end{array}$ & \begin{tabular}{l|}
1 \\
$\%$
\end{tabular} & $\begin{array}{l}0 \\
\%\end{array}$ & $\begin{array}{l}0 \\
\%\end{array}$ & $\begin{array}{l}20 \\
\%\end{array}$ & $\begin{array}{l}3 \\
\%\end{array}$ & $\begin{array}{l}0 \\
\%\end{array}$ & $\begin{array}{l}0 \\
\%\end{array}$ & $\begin{array}{l}0 \\
\%\end{array}$ & $\begin{array}{l}0 \\
\%\end{array}$ & $\begin{array}{l}0 \\
\%\end{array}$ & $\begin{array}{l}0 \\
\%\end{array}$ & $\begin{array}{l}0 \\
\%\end{array}$ & $\begin{array}{l}0 \\
\%\end{array}$ & $\begin{array}{l}0 \\
\%\end{array}$ & $\begin{array}{l}3 \\
3 \\
\%\end{array}$ & $\begin{array}{l}0 \\
\%\end{array}$ \\
\hline $70 \mathrm{~s}$ & $3 \%$ & $\begin{array}{l}0 \\
\%\end{array}$ & $\begin{array}{l}0 \\
\%\end{array}$ & $\begin{array}{l}3 \\
1 \\
\%\end{array}$ & \begin{tabular}{l|}
6 \\
$\%$
\end{tabular} & $\begin{array}{l}0 \\
\%\end{array}$ & $\begin{array}{l}0 \\
\%\end{array}$ & $\begin{array}{l}0 \\
\%\end{array}$ & $\begin{array}{l}0 \\
\%\end{array}$ & $\begin{array}{l}0 \\
\%\end{array}$ & $\begin{array}{l}3 \\
6 \\
\%\end{array}$ & $\begin{array}{l}0 \\
\%\end{array}$ & $\begin{array}{l}0 \\
\%\end{array}$ & $\begin{array}{l}0 \\
\%\end{array}$ & $\begin{array}{l}0 \\
\%\end{array}$ & $\begin{array}{l}0 \\
\%\end{array}$ & \begin{tabular}{l|}
0 \\
$\%$
\end{tabular} & $\begin{array}{l}0 \\
\%\end{array}$ & $\begin{array}{l}0 \\
\%\end{array}$ & $\begin{array}{l}0 \\
\%\end{array}$ \\
\hline $80 \mathrm{~s}$ & $\begin{array}{l}13 \\
\%\end{array}$ & $\begin{array}{l}5 \\
\%\end{array}$ & $\begin{array}{l}2 \\
4 \\
\%\end{array}$ & $\begin{array}{l}2 \\
3 \\
\%\end{array}$ & $\begin{array}{l}1 \\
4 \\
\%\end{array}$ & $\begin{array}{l}5 \\
\%\end{array}$ & $\begin{array}{l}1 \\
0 \\
\%\end{array}$ & $\begin{array}{l}40 \\
\%\end{array}$ & $\begin{array}{l}6 \\
\%\end{array}$ & $\begin{array}{l}2 \\
6 \\
\%\end{array}$ & $\begin{array}{l}1 \\
8 \\
\%\end{array}$ & $\begin{array}{l}6 \\
\%\end{array}$ & $\begin{array}{l}0 \\
\%\end{array}$ & $\begin{array}{l}0 \\
\%\end{array}$ & $\begin{array}{l}0 \\
\%\end{array}$ & $\begin{array}{l}1 \\
0 \\
0 \\
\%\end{array}$ & $\begin{array}{l}0 \\
\%\end{array}$ & $\begin{array}{l}0 \\
\%\end{array}$ & $\begin{array}{l}3 \\
3 \\
\%\end{array}$ & $\begin{array}{l}1 \\
0 \\
0 \\
\%\end{array}$ \\
\hline $90 \mathrm{~s}$ & $\begin{array}{l}28 \\
\%\end{array}$ & $\begin{array}{l}3 \\
9 \\
\%\end{array}$ & $\begin{array}{l}1 \\
6 \\
\%\end{array}$ & $\begin{array}{l}0 \\
\%\end{array}$ & $\begin{array}{l}2 \\
9 \\
\%\end{array}$ & $\begin{array}{l}36 \\
\%\end{array}$ & $\begin{array}{l}3 \\
0 \\
\%\end{array}$ & $\begin{array}{l}40 \\
\%\end{array}$ & $\begin{array}{l}4 \\
2 \\
\%\end{array}$ & $\begin{array}{l}2 \\
2 \\
\%\end{array}$ & $\begin{array}{l}0 \\
\%\end{array}$ & $\begin{array}{l}5 \\
0 \\
\%\end{array}$ & $\begin{array}{l}0 \\
\%\end{array}$ & $\begin{array}{l}0 \\
\%\end{array}$ & $\begin{array}{l}3 \\
8 \\
\%\end{array}$ & $\begin{array}{l}0 \\
\%\end{array}$ & $\begin{array}{l}0 \\
\%\end{array}$ & $\begin{array}{l}1 \\
0 \\
0 \\
\%\end{array}$ & $\begin{array}{l}3 \\
3 \\
\%\end{array}$ & $\begin{array}{l}0 \\
\%\end{array}$ \\
\hline $20 \mathrm{~s}$ & $9 \%$ & $\begin{array}{l}1 \\
5 \\
\% \\
\end{array}$ & $\begin{array}{l}0 \\
\%\end{array}$ & $\begin{array}{l}0 \\
\%\end{array}$ & $\begin{array}{l}6 \\
\%\end{array}$ & $\begin{array}{l}9 \\
\%\end{array}$ & $\begin{array}{l}2 \\
0 \\
\% \\
\end{array}$ & $\begin{array}{l}0 \\
\%\end{array}$ & $\begin{array}{l}1 \\
1 \\
\% \\
\end{array}$ & $\begin{array}{l}0 \\
\%\end{array}$ & $\begin{array}{l}0 \\
\%\end{array}$ & $\begin{array}{l}1 \\
3 \\
\%\end{array}$ & $\begin{array}{l}0 \\
\%\end{array}$ & $\begin{array}{l}0 \\
\%\end{array}$ & $\begin{array}{l}2 \\
5 \\
\% \\
\end{array}$ & $\begin{array}{l}0 \\
\%\end{array}$ & $\begin{array}{l}0 \\
\%\end{array}$ & $\begin{array}{l}0 \\
\%\end{array}$ & $\begin{array}{l}0 \\
\%\end{array}$ & $\begin{array}{l}0 \\
\%\end{array}$ \\
\hline $70 \mathrm{~s} \& 80 \mathrm{~s}$ & $8 \%$ & $\begin{array}{l}0 \\
\%\end{array}$ & $\begin{array}{l}1 \\
9 \\
\%\end{array}$ & $\begin{array}{l}2 \\
3 \\
\%\end{array}$ & $\begin{array}{l}7 \\
\%\end{array}$ & $\begin{array}{l}9 \\
\%\end{array}$ & $\begin{array}{l}1 \\
0 \\
\%\end{array}$ & $\begin{array}{l}0 \\
\%\end{array}$ & $\begin{array}{l}0 \\
\%\end{array}$ & $\begin{array}{l}1 \\
3 \\
\%\end{array}$ & $\begin{array}{l}1 \\
8 \\
\%\end{array}$ & $\begin{array}{l}0 \\
\%\end{array}$ & $\begin{array}{l}3 \\
3 \\
\%\end{array}$ & $\begin{array}{l}0 \\
\%\end{array}$ & $\begin{array}{l}0 \\
\%\end{array}$ & $\begin{array}{l}0 \\
\%\end{array}$ & $\begin{array}{l}1 \\
0 \\
0 \\
\%\end{array}$ & $\begin{array}{l}0 \\
\%\end{array}$ & $\begin{array}{l}0 \\
\%\end{array}$ & $\begin{array}{l}0 \\
\%\end{array}$ \\
\hline 80s \& 90s & $\begin{array}{l}12 \\
\%\end{array}$ & $\begin{array}{l}1 \\
2 \\
\% \\
\end{array}$ & $\begin{array}{l}1 \\
6 \\
\% \\
\end{array}$ & $\begin{array}{l}0 \\
\%\end{array}$ & $\begin{array}{l}1 \\
1 \\
\% \\
\end{array}$ & $\begin{array}{l}18 \\
\%\end{array}$ & $\begin{array}{l}0 \\
\%\end{array}$ & $\begin{array}{l}0 \\
\%\end{array}$ & $\begin{array}{l}1 \\
4 \\
\% \\
\end{array}$ & $\begin{array}{l}1 \\
3 \\
\% \\
\end{array}$ & $\begin{array}{l}0 \\
\%\end{array}$ & $\begin{array}{l}6 \\
\%\end{array}$ & $\begin{array}{l}5 \\
0 \\
\% \\
\end{array}$ & $\begin{array}{l}0 \\
\%\end{array}$ & $\begin{array}{l}0 \\
\%\end{array}$ & $\begin{array}{l}0 \\
\%\end{array}$ & $\begin{array}{l}0 \\
\%\end{array}$ & $\begin{array}{l}0 \\
\%\end{array}$ & $\begin{array}{l}0 \\
\%\end{array}$ & $\begin{array}{l}0 \\
\%\end{array}$ \\
\hline $90 s \& 20 s$ & $\begin{array}{l}10 \\
\%\end{array}$ & $\begin{array}{l}1 \\
6 \\
\% \\
\end{array}$ & $\begin{array}{l}0 \\
\%\end{array}$ & $\begin{array}{l}0 \\
\%\end{array}$ & $\begin{array}{l}7 \\
\%\end{array}$ & $\begin{array}{l}14 \\
\%\end{array}$ & $\begin{array}{l}1 \\
0 \\
\% \\
\end{array}$ & $\begin{array}{l}0 \\
\%\end{array}$ & $\begin{array}{l}1 \\
4 \\
\% \\
\end{array}$ & $\begin{array}{l}0 \\
\%\end{array}$ & $\begin{array}{l}0 \\
\%\end{array}$ & $\begin{array}{l}1 \\
9 \\
\% \\
\end{array}$ & $\begin{array}{l}0 \\
\%\end{array}$ & $\begin{array}{l}0 \\
\%\end{array}$ & $\begin{array}{l}1 \\
3 \\
\% \\
\end{array}$ & $\begin{array}{l}0 \\
\%\end{array}$ & $\begin{array}{l}0 \\
\%\end{array}$ & $\begin{array}{l}0 \\
\%\end{array}$ & $\begin{array}{l}0 \\
\%\end{array}$ & $\begin{array}{l}0 \\
\%\end{array}$ \\
\hline $50 \mathrm{~s}-90 \mathrm{~s}$ & $1 \%$ & $\begin{array}{l}0 \\
\% \\
\end{array}$ & $\begin{array}{l}3 \\
\% \\
\end{array}$ & $\begin{array}{l}0 \\
\% \\
\end{array}$ & $\begin{array}{l}1 \\
\%\end{array}$ & $\begin{array}{l}0 \\
\% \\
\end{array}$ & $\begin{array}{l}0 \\
\% \\
\end{array}$ & $\begin{array}{l}0 \\
\% \\
\end{array}$ & $\begin{array}{l}0 \\
\% \\
\end{array}$ & $\begin{array}{l}4 \\
\% \\
\end{array}$ & $\begin{array}{l}0 \\
\% \\
\end{array}$ & $\begin{array}{l}0 \\
\% \\
\end{array}$ & $\begin{array}{l}0 \\
\% \\
\end{array}$ & $\begin{array}{l}0 \\
\% \\
\end{array}$ & $\begin{array}{l}0 \\
\% \\
\end{array}$ & $\begin{array}{l}0 \\
\% \\
\end{array}$ & $\begin{array}{l}0 \\
\% \\
\end{array}$ & $\begin{array}{l}0 \\
\% \\
\end{array}$ & $\begin{array}{l}0 \\
\% \\
\end{array}$ & $\begin{array}{l}0 \\
\% \\
\end{array}$ \\
\hline $\begin{array}{lll}60 s, & 70 s \quad \& \\
80 s & & \\
\end{array}$ & $2 \%$ & $\begin{array}{l}0 \\
\% \\
\end{array}$ & $\begin{array}{l}5 \\
\% \\
\end{array}$ & $\begin{array}{l}0 \\
\%\end{array}$ & \begin{tabular}{l|}
3 \\
$\%$ \\
\end{tabular} & $\begin{array}{l}0 \\
\% \\
\end{array}$ & $\begin{array}{l}0 \\
\% \\
\end{array}$ & $\begin{array}{l}0 \\
\% \\
\end{array}$ & $\begin{array}{l}0 \\
\% \\
\end{array}$ & $\begin{array}{l}9 \\
\% \\
\end{array}$ & $\begin{array}{l}0 \\
\% \\
\end{array}$ & $\begin{array}{l}0 \\
\% \\
\end{array}$ & $\begin{array}{l}0 \\
\% \\
\end{array}$ & $\begin{array}{l}0 \\
\%\end{array}$ & $\begin{array}{l}0 \\
\% \\
\end{array}$ & $\begin{array}{l}0 \\
\%\end{array}$ & $\begin{array}{l}0 \\
\% \\
\end{array}$ & $\begin{array}{l}0 \\
\% \\
\end{array}$ & $\begin{array}{l}0 \\
\%\end{array}$ & $\begin{array}{l}0 \\
\% \\
\end{array}$ \\
\hline $\begin{array}{lll}70 \mathrm{~s}, & 80 \mathrm{~s} \quad \& \\
90 \mathrm{~s} & & \\
\end{array}$ & $1 \%$ & $\begin{array}{l}1 \\
\%\end{array}$ & \begin{tabular}{l|}
0 \\
$\%$ \\
\end{tabular} & $\begin{array}{l}0 \\
\%\end{array}$ & \begin{tabular}{l|}
1 \\
$\%$
\end{tabular} & $\begin{array}{l}0 \\
\% \\
\end{array}$ & $\begin{array}{l}0 \\
\% \\
\end{array}$ & $\begin{array}{l}0 \\
\% \\
\end{array}$ & $\begin{array}{l}3 \\
\% \\
\end{array}$ & $\begin{array}{l}0 \\
\% \\
\end{array}$ & $\begin{array}{l}0 \\
\% \\
\end{array}$ & $\begin{array}{l}0 \\
\% \\
\end{array}$ & $\begin{array}{l}0 \\
\% \\
\end{array}$ & $\begin{array}{l}0 \\
\%\end{array}$ & $\begin{array}{l}0 \\
\% \\
\end{array}$ & $\begin{array}{l}0 \\
\%\end{array}$ & $\begin{array}{l}0 \\
\% \\
\end{array}$ & $\begin{array}{l}0 \\
\% \\
\end{array}$ & $\begin{array}{l}0 \\
\%\end{array}$ & $\begin{array}{l}0 \\
\% \\
\end{array}$ \\
\hline $\begin{array}{l}70 s, 80 s, 90 s \\
\& 20 s\end{array}$ & $2 \%$ & $\begin{array}{l}1 \\
\%\end{array}$ & $\begin{array}{l}5 \\
\%\end{array}$ & $\begin{array}{l}0 \\
\%\end{array}$ & \begin{tabular}{l|}
3 \\
$\%$
\end{tabular} & $\begin{array}{l}5 \\
\%\end{array}$ & $\begin{array}{l}0 \\
\%\end{array}$ & $\begin{array}{l}0 \\
\%\end{array}$ & $\begin{array}{l}3 \\
\%\end{array}$ & $\begin{array}{l}4 \\
\%\end{array}$ & $\begin{array}{l}0 \\
\%\end{array}$ & $\begin{array}{l}0 \\
\%\end{array}$ & $\begin{array}{l}1 \\
7 \\
\% \\
\end{array}$ & $\begin{array}{l}0 \\
\%\end{array}$ & $\begin{array}{l}0 \\
\%\end{array}$ & $\begin{array}{l}0 \\
\%\end{array}$ & $\begin{array}{l}0 \\
\%\end{array}$ & $\begin{array}{l}0 \\
\%\end{array}$ & $\begin{array}{l}0 \\
\%\end{array}$ & $\begin{array}{l}0 \\
\%\end{array}$ \\
\hline $\begin{array}{lll}80 s, & 90 s \quad \& \\
20 s & & \\
\end{array}$ & $2 \%$ & $\begin{array}{l}3 \\
\% \\
\end{array}$ & $\begin{array}{l}0 \\
\% \\
\end{array}$ & $\begin{array}{l}0 \\
\% \\
\end{array}$ & $\begin{array}{l}0 \\
\% \\
\end{array}$ & $\begin{array}{l}5 \\
\% \\
\end{array}$ & $\begin{array}{l}0 \\
\% \\
\end{array}$ & $\begin{array}{l}0 \\
\% \\
\end{array}$ & $\begin{array}{l}0 \\
\% \\
\end{array}$ & $\begin{array}{l}0 \\
\% \\
\end{array}$ & $\begin{array}{l}0 \\
\% \\
\end{array}$ & $\begin{array}{l}6 \\
\% \\
\end{array}$ & $\begin{array}{l}0 \\
\% \\
\end{array}$ & $\begin{array}{l}0 \\
\% \\
\end{array}$ & $\begin{array}{l}0 \\
\% \\
\end{array}$ & $\begin{array}{l}0 \\
\% \\
\end{array}$ & $\begin{array}{l}0 \\
\% \\
\end{array}$ & $\begin{array}{l}0 \\
\% \\
\end{array}$ & $\begin{array}{l}0 \\
\% \\
\end{array}$ & $\begin{array}{l}0 \\
\% \\
\end{array}$ \\
\hline Not Given & $9 \%$ & 7 & 8 & 2 & 1 & 0 & 2 & 0 & 6 & 9 & 2 & 0 & 0 & 0 & 2 & 0 & 0 & 0 & 0 & 0 \\
\hline
\end{tabular}


Mehreen et al. / Publication Trends and Methodological Advancements

\begin{tabular}{|c|c|c|c|c|c|c|c|c|c|c|c|c|c|c|c|c|c|c|c|c|}
\hline & & $\%$ & $\%$ & $\begin{array}{l}3 \\
\%\end{array}$ & $\begin{array}{l}0 \\
\%\end{array}$ & $\%$ & $\begin{array}{l}0 \\
\%\end{array}$ & $\%$ & $\%$ & $\%$ & $\begin{array}{l}7 \\
\%\end{array}$ & $\%$ & $\%$ & $\%$ & $\begin{array}{l}5 \\
\%\end{array}$ & $\%$ & $\%$ & $\%$ & $\%$ & $\%$ \\
\hline \multicolumn{21}{|l|}{ Time Series } \\
\hline $\begin{array}{l}\text { Cross- } \\
\text { Sectional }\end{array}$ & $\begin{array}{l}43 \\
\%\end{array}$ & $\begin{array}{l}4 \\
4 \\
\%\end{array}$ & $\begin{array}{l}3 \\
8 \\
\%\end{array}$ & $\begin{array}{l}5 \\
4 \\
\%\end{array}$ & $\begin{array}{l}5 \\
3 \\
\%\end{array}$ & $\begin{array}{l}32 \\
\%\end{array}$ & $\begin{array}{l}4 \\
0 \\
\%\end{array}$ & $\begin{array}{l}40 \\
\%\end{array}$ & $\begin{array}{l}4 \\
7 \\
\%\end{array}$ & $\begin{array}{l}5 \\
7 \\
\%\end{array}$ & $\begin{array}{l}6 \\
4 \\
\%\end{array}$ & \begin{tabular}{l|}
4 \\
4 \\
$\%$
\end{tabular} & $\begin{array}{l}0 \\
\%\end{array}$ & $\begin{array}{l}0 \\
\%\end{array}$ & $\begin{array}{l}5 \\
0 \\
\%\end{array}$ & $\begin{array}{l}0 \\
\%\end{array}$ & $\begin{array}{l}0 \\
\%\end{array}$ & $\begin{array}{l}1 \\
0 \\
0 \\
\%\end{array}$ & $\begin{array}{l}3 \\
3 \\
\%\end{array}$ & $\begin{array}{l}0 \\
\%\end{array}$ \\
\hline Longitudinal & $\begin{array}{l}50 \\
\%\end{array}$ & $\begin{array}{l}4 \\
8 \\
\%\end{array}$ & $\begin{array}{l}5 \\
7 \\
\%\end{array}$ & $\begin{array}{l}3 \\
8 \\
\%\end{array}$ & $\begin{array}{l}4 \\
1 \\
\%\end{array}$ & $\begin{array}{l}55 \\
\%\end{array}$ & $\begin{array}{l}5 \\
0 \\
\%\end{array}$ & $\begin{array}{l}60 \\
\%\end{array}$ & $\begin{array}{l}4 \\
7 \\
\%\end{array}$ & $\begin{array}{l}3 \\
9 \\
\%\end{array}$ & $\begin{array}{l}2 \\
7 \\
\%\end{array}$ & \begin{tabular}{l|}
4 \\
4 \\
$\%$
\end{tabular} & $\begin{array}{l}8 \\
3 \\
\%\end{array}$ & $\begin{array}{l}0 \\
\%\end{array}$ & $\begin{array}{l}3 \\
8 \\
\%\end{array}$ & $\begin{array}{l}1 \\
0 \\
0 \\
\%\end{array}$ & $\begin{array}{l}1 \\
0 \\
0 \\
\% \\
\end{array}$ & $\begin{array}{l}0 \\
\%\end{array}$ & $\begin{array}{l}6 \\
7 \\
\%\end{array}$ & $\begin{array}{l}1 \\
0 \\
0 \\
\%\end{array}$ \\
\hline Pooled & $2 \%$ & $\begin{array}{l}1 \\
\%\end{array}$ & $\begin{array}{l}3 \\
\%\end{array}$ & $\begin{array}{l}0 \\
\%\end{array}$ & $\begin{array}{l}1 \\
\%\end{array}$ & $\begin{array}{l}5 \\
\%\end{array}$ & $\begin{array}{l}0 \\
\%\end{array}$ & $\begin{array}{l}0 \\
\%\end{array}$ & $\begin{array}{l}3 \\
\%\end{array}$ & $\begin{array}{l}0 \\
\%\end{array}$ & $\begin{array}{l}0 \\
\%\end{array}$ & $\begin{array}{l}0 \\
\%\end{array}$ & $\begin{array}{l}1 \\
7 \\
\%\end{array}$ & $\begin{array}{l}0 \\
\%\end{array}$ & $\begin{array}{l}0 \\
\%\end{array}$ & $\begin{array}{l}0 \\
\%\end{array}$ & $\begin{array}{l}0 \\
\%\end{array}$ & $\begin{array}{l}0 \\
\%\end{array}$ & $\begin{array}{l}0 \\
\%\end{array}$ & $\begin{array}{l}0 \\
\%\end{array}$ \\
\hline Panel & $5 \%$ & $\begin{array}{l}7 \\
\%\end{array}$ & $\begin{array}{l}3 \\
\%\end{array}$ & $\begin{array}{l}0 \\
\%\end{array}$ & $\begin{array}{l}3 \\
\%\end{array}$ & $\begin{array}{l}9 \\
\%\end{array}$ & $\begin{array}{l}1 \\
0 \\
\%\end{array}$ & $\begin{array}{l}0 \\
\%\end{array}$ & $\begin{array}{l}3 \\
\%\end{array}$ & $\begin{array}{l}4 \\
\%\end{array}$ & $\begin{array}{l}0 \\
\%\end{array}$ & \begin{tabular}{l|}
1 \\
3 \\
$\%$
\end{tabular} & $\begin{array}{l}0 \\
\%\end{array}$ & $\begin{array}{l}0 \\
\%\end{array}$ & $\begin{array}{l}1 \\
3 \\
\% \\
\end{array}$ & $\begin{array}{l}0 \\
\%\end{array}$ & $\begin{array}{l}0 \\
\%\end{array}$ & $\begin{array}{l}0 \\
\%\end{array}$ & $\begin{array}{l}0 \\
\%\end{array}$ & $\begin{array}{l}0 \\
\%\end{array}$ \\
\hline Not Given & $1 \%$ & $\begin{array}{l}0 \\
\%\end{array}$ & $\begin{array}{l}0 \\
\%\end{array}$ & $\begin{array}{l}8 \\
\%\end{array}$ & $\begin{array}{l}1 \\
\%\end{array}$ & $\begin{array}{l}0 \\
\%\end{array}$ & $\begin{array}{l}0 \\
\%\end{array}$ & $\begin{array}{l}0 \\
\%\end{array}$ & $\begin{array}{l}0 \\
\%\end{array}$ & $\begin{array}{l}0 \\
\%\end{array}$ & $\begin{array}{l}9 \\
\%\end{array}$ & $\begin{array}{l}0 \\
\%\end{array}$ & $\begin{array}{l}0 \\
\%\end{array}$ & $\begin{array}{l}0 \\
\%\end{array}$ & $\begin{array}{l}0 \\
\%\end{array}$ & $\begin{array}{l}0 \\
\%\end{array}$ & $\begin{array}{l}0 \\
\%\end{array}$ & $\begin{array}{l}0 \\
\%\end{array}$ & $\begin{array}{l}0 \\
\%\end{array}$ & $\begin{array}{l}0 \\
\%\end{array}$ \\
\hline \multicolumn{21}{|l|}{$\begin{array}{l}\text { Statistical } \\
\text { Techniques }\end{array}$} \\
\hline $\begin{array}{l}\text { Wilcoxon } \\
\text { Test (WT) }\end{array}$ & $5 \%$ & $\begin{array}{l}3 \\
\%\end{array}$ & $\begin{array}{l}8 \\
\%\end{array}$ & $\begin{array}{l}8 \\
\%\end{array}$ & $\begin{array}{l}6 \\
\%\end{array}$ & $\begin{array}{l}9 \\
\%\end{array}$ & $\begin{array}{l}0 \\
\%\end{array}$ & $\begin{array}{l}0 \\
\%\end{array}$ & $\begin{array}{l}3 \\
\%\end{array}$ & $\begin{array}{l}9 \\
\%\end{array}$ & $\begin{array}{l}9 \\
\%\end{array}$ & $\begin{array}{l}6 \\
\%\end{array}$ & $\begin{array}{l}1 \\
7 \\
\%\end{array}$ & $\begin{array}{l}0 \\
\%\end{array}$ & $\begin{array}{l}0 \\
\%\end{array}$ & $\begin{array}{l}0 \\
\%\end{array}$ & $\begin{array}{l}0 \\
\%\end{array}$ & $\begin{array}{l}0 \\
\%\end{array}$ & $\begin{array}{l}0 \\
\%\end{array}$ & $\begin{array}{l}0 \\
\%\end{array}$ \\
\hline $\begin{array}{l}\text { Univariate } \\
\text { tests (UT) }\end{array}$ & $\begin{array}{l}10 \\
\%\end{array}$ & $\begin{array}{l}1 \\
2 \\
\%\end{array}$ & $\begin{array}{l}8 \\
\%\end{array}$ & $\begin{array}{l}8 \\
\%\end{array}$ & $\begin{array}{l}7 \\
\%\end{array}$ & $\begin{array}{l}14 \\
\%\end{array}$ & $\begin{array}{l}1 \\
0 \\
\%\end{array}$ & $\begin{array}{l}20 \\
\%\end{array}$ & $\begin{array}{l}8 \\
\%\end{array}$ & $\begin{array}{l}4 \\
\%\end{array}$ & $\begin{array}{l}9 \\
\%\end{array}$ & \begin{tabular}{l|}
1 \\
3 \\
$\%$
\end{tabular} & $\begin{array}{l}1 \\
7 \\
\%\end{array}$ & $\begin{array}{l}0 \\
\%\end{array}$ & $\begin{array}{l}1 \\
3 \\
\%\end{array}$ & $\begin{array}{l}0 \\
\%\end{array}$ & $\begin{array}{l}0 \\
\%\end{array}$ & $\begin{array}{l}0 \\
\%\end{array}$ & $\begin{array}{l}3 \\
3 \\
\%\end{array}$ & $\begin{array}{l}0 \\
\%\end{array}$ \\
\hline $\begin{array}{l}\text { Multivariate } \\
\text { Tests (MT) }\end{array}$ & $6 \%$ & $\begin{array}{l}8 \\
\%\end{array}$ & $\begin{array}{l}3 \\
\%\end{array}$ & $\begin{array}{l}0 \\
\%\end{array}$ & $\begin{array}{l}3 \\
\%\end{array}$ & $\begin{array}{l}14 \\
\%\end{array}$ & $\begin{array}{l}0 \\
\%\end{array}$ & $\begin{array}{l}20 \\
\%\end{array}$ & $\begin{array}{l}6 \\
\%\end{array}$ & $\begin{array}{l}0 \\
\%\end{array}$ & $\begin{array}{l}0 \\
\%\end{array}$ & $\begin{array}{l}1 \\
9 \\
\%\end{array}$ & $\begin{array}{l}0 \\
\%\end{array}$ & $\begin{array}{l}0 \\
\%\end{array}$ & $\begin{array}{l}0 \\
\%\end{array}$ & $\begin{array}{l}0 \\
\%\end{array}$ & $\begin{array}{l}0 \\
\%\end{array}$ & $\begin{array}{l}0 \\
\%\end{array}$ & $\begin{array}{l}3 \\
3 \\
\%\end{array}$ & $\begin{array}{l}0 \\
\%\end{array}$ \\
\hline $\begin{array}{l}\text { Event Study } \\
\text { (ES) }\end{array}$ & $2 \%$ & $\begin{array}{l}1 \\
\%\end{array}$ & $\begin{array}{l}3 \\
\% \\
\end{array}$ & $\begin{array}{l}0 \\
\%\end{array}$ & $\begin{array}{l}1 \\
\% \\
\end{array}$ & $\begin{array}{l}5 \\
\% \\
\end{array}$ & $\begin{array}{l}0 \\
\% \\
\end{array}$ & $\begin{array}{l}0 \\
\% \\
\end{array}$ & $\begin{array}{l}0 \\
\%\end{array}$ & $\begin{array}{l}4 \\
\% \\
\end{array}$ & $\begin{array}{l}0 \\
\% \\
\end{array}$ & $\begin{array}{l}6 \\
\% \\
\end{array}$ & $\begin{array}{l}0 \\
\% \\
\end{array}$ & $\begin{array}{l}0 \\
\%\end{array}$ & $\begin{array}{l}0 \\
\% \\
\end{array}$ & $\begin{array}{l}0 \\
\%\end{array}$ & $\begin{array}{l}0 \\
\% \\
\end{array}$ & $\begin{array}{l}0 \\
\% \\
\end{array}$ & $\begin{array}{l}0 \\
\% \\
\end{array}$ & $\begin{array}{l}0 \\
\% \\
\end{array}$ \\
\hline Regression ${ }^{\circledR}$ & $\begin{array}{l}42 \\
\%\end{array}$ & $\begin{array}{l}4 \\
4 \\
\%\end{array}$ & $\begin{array}{l}4 \\
9 \\
\%\end{array}$ & $\begin{array}{l}8 \\
\%\end{array}$ & $\begin{array}{l}4 \\
0 \\
\%\end{array}$ & $\begin{array}{l}32 \\
\%\end{array}$ & $\begin{array}{l}5 \\
0 \\
\%\end{array}$ & $\begin{array}{l}0 \\
\%\end{array}$ & $\begin{array}{l}4 \\
7 \\
\%\end{array}$ & $\begin{array}{l}4 \\
3 \\
\%\end{array}$ & $\begin{array}{l}9 \\
\%\end{array}$ & \begin{tabular}{l|}
1 \\
9 \\
$\%$
\end{tabular} & $\begin{array}{l}6 \\
7 \\
\%\end{array}$ & $\begin{array}{l}0 \\
\%\end{array}$ & $\begin{array}{l}5 \\
0 \\
\%\end{array}$ & $\begin{array}{l}1 \\
0 \\
0 \\
\%\end{array}$ & $\begin{array}{l}0 \\
\%\end{array}$ & $\begin{array}{l}0 \\
\%\end{array}$ & $\begin{array}{l}0 \\
\%\end{array}$ & $\begin{array}{l}0 \\
\%\end{array}$ \\
\hline $\begin{array}{l}\text { OLS } \\
\text { regression } \\
(\text { OLS) }\end{array}$ & $\begin{array}{l}27 \\
\%\end{array}$ & $\begin{array}{l}3 \\
2 \\
\%\end{array}$ & $\begin{array}{l}1 \\
4 \\
\%\end{array}$ & $\begin{array}{l}3 \\
8 \\
\%\end{array}$ & $\begin{array}{l}3 \\
1 \\
\%\end{array}$ & $\begin{array}{l}9 \\
\%\end{array}$ & $\begin{array}{l}2 \\
0 \\
\%\end{array}$ & $\begin{array}{l}40 \\
\%\end{array}$ & $\begin{array}{l}3 \\
9 \\
\%\end{array}$ & $\begin{array}{l}1 \\
7 \\
\%\end{array}$ & $\begin{array}{l}3 \\
6 \\
\%\end{array}$ & \begin{tabular}{l|}
1 \\
3 \\
$\%$
\end{tabular} & $\begin{array}{l}0 \\
\%\end{array}$ & $\begin{array}{l}0 \\
\%\end{array}$ & $\begin{array}{l}1 \\
3 \\
\%\end{array}$ & $\begin{array}{l}0 \\
\%\end{array}$ & $\begin{array}{l}1 \\
0 \\
0 \\
\%\end{array}$ & $\begin{array}{l}1 \\
0 \\
0 \\
\%\end{array}$ & $\begin{array}{l}3 \\
3 \\
\%\end{array}$ & $\begin{array}{l}0 \\
\%\end{array}$ \\
\hline $\begin{array}{l}\text { Logit } \\
\text { Regression } \\
\text { (LR) } \\
\end{array}$ & $\begin{array}{l}21 \\
\%\end{array}$ & $\begin{array}{l}2 \\
4 \\
\% \\
\end{array}$ & $\begin{array}{l}1 \\
6 \\
\% \\
\end{array}$ & $\begin{array}{l}1 \\
5 \\
\% \\
\end{array}$ & $\begin{array}{l}2 \\
1 \\
\% \\
\end{array}$ & $\begin{array}{l}23 \\
\%\end{array}$ & $\begin{array}{l}3 \\
0 \\
\% \\
\end{array}$ & $\begin{array}{l}0 \\
\%\end{array}$ & $\begin{array}{l}2 \\
2 \\
\% \\
\end{array}$ & $\begin{array}{l}2 \\
2 \\
\% \\
\end{array}$ & $\begin{array}{l}1 \\
8 \\
\% \\
\end{array}$ & \begin{tabular}{l|}
2 \\
5 \\
$\%$ \\
\end{tabular} & $\begin{array}{l}1 \\
7 \\
\% \\
\end{array}$ & $\begin{array}{l}0 \\
\%\end{array}$ & $\begin{array}{l}3 \\
8 \\
\% \\
\end{array}$ & $\begin{array}{l}0 \\
\%\end{array}$ & $\begin{array}{l}0 \\
\%\end{array}$ & $\begin{array}{l}0 \\
\%\end{array}$ & $\begin{array}{l}0 \\
\%\end{array}$ & $\begin{array}{l}0 \\
\%\end{array}$ \\
\hline $\begin{array}{l}\text { probit model } \\
(\mathrm{PM})\end{array}$ & $5 \%$ & $\begin{array}{l}4 \\
\%\end{array}$ & $\begin{array}{l}3 \\
\%\end{array}$ & $\begin{array}{l}1 \\
5 \\
\%\end{array}$ & $\begin{array}{l}4 \\
\%\end{array}$ & $\begin{array}{l}9 \\
\%\end{array}$ & $\begin{array}{l}1 \\
0 \\
\%\end{array}$ & $\begin{array}{l}0 \\
\%\end{array}$ & $\begin{array}{l}6 \\
\%\end{array}$ & $\begin{array}{l}0 \\
\%\end{array}$ & $\begin{array}{l}9 \\
\%\end{array}$ & $\begin{array}{l}6 \\
\%\end{array}$ & $\begin{array}{l}1 \\
7 \\
\%\end{array}$ & $\begin{array}{l}0 \\
\%\end{array}$ & $\begin{array}{l}0 \\
\%\end{array}$ & $\begin{array}{l}0 \\
\%\end{array}$ & $\begin{array}{l}1 \\
0 \\
0 \\
\%\end{array}$ & $\begin{array}{l}0 \\
\%\end{array}$ & $\begin{array}{l}0 \\
\%\end{array}$ & $\begin{array}{l}0 \\
\%\end{array}$ \\
\hline $\begin{array}{l}\text { linear / non } \\
\text { linear } \\
\text { specification( } \\
\text { MP) }\end{array}$ & $6 \%$ & $\begin{array}{l}7 \\
\%\end{array}$ & $\begin{array}{l}5 \\
\%\end{array}$ & $\begin{array}{l}0 \\
\%\end{array}$ & $\begin{array}{l}1 \\
\%\end{array}$ & $\begin{array}{l}14 \\
\%\end{array}$ & $\begin{array}{l}0 \\
\%\end{array}$ & $\begin{array}{l}40 \\
\%\end{array}$ & $\begin{array}{l}3 \\
\%\end{array}$ & $\begin{array}{l}0 \\
\%\end{array}$ & $\begin{array}{l}0 \\
\%\end{array}$ & \begin{tabular}{l|}
1 \\
9 \\
$\%$
\end{tabular} & $\begin{array}{l}0 \\
\%\end{array}$ & $\begin{array}{l}0 \\
\%\end{array}$ & $\begin{array}{l}0 \\
\%\end{array}$ & $\begin{array}{l}0 \\
\%\end{array}$ & $\begin{array}{l}0 \\
\%\end{array}$ & $\begin{array}{l}0 \\
\%\end{array}$ & $\begin{array}{l}6 \\
7 \\
\%\end{array}$ & $\begin{array}{l}0 \\
\%\end{array}$ \\
\hline $\begin{array}{l}\text { Maximum } \\
\text { likelihood }\end{array}$ & $2 \%$ & $\begin{array}{l}0 \\
\%\end{array}$ & $\begin{array}{l}3 \\
\%\end{array}$ & $\begin{array}{l}1 \\
5\end{array}$ & $\begin{array}{l}1 \\
\%\end{array}$ & $\begin{array}{l}0 \\
\%\end{array}$ & $\begin{array}{l}0 \\
\%\end{array}$ & $\begin{array}{l}40 \\
\%\end{array}$ & $\begin{array}{l}0 \\
\%\end{array}$ & $\begin{array}{l}0 \\
\%\end{array}$ & $\begin{array}{l}9 \\
\%\end{array}$ & $\begin{array}{l}0 \\
\%\end{array}$ & $\begin{array}{l}0 \\
\%\end{array}$ & $\begin{array}{l}0 \\
\%\end{array}$ & $\begin{array}{l}0 \\
\%\end{array}$ & $\begin{array}{l}0 \\
\%\end{array}$ & $\begin{array}{l}0 \\
\%\end{array}$ & $\begin{array}{l}0 \\
\%\end{array}$ & $\begin{array}{l}3 \\
3\end{array}$ & $\begin{array}{l}1 \\
0\end{array}$ \\
\hline
\end{tabular}


Mehreen et al. / Publication Trends and Methodological Advancements

\begin{tabular}{|c|c|c|c|c|c|c|c|c|c|c|c|c|c|c|c|c|c|c|c|c|}
\hline $\begin{array}{l}\text { estimation(M } \\
\text { L) }\end{array}$ & & & & $\%$ & & & & & & & & & & & & & & & $\%$ & $\begin{array}{l}0 \\
\%\end{array}$ \\
\hline Correlation & 12 & 1 & 1 & 0 & 1 & 9 & 2 & 0 & 1 & 1 & 0 & 1 & 0 & 0 & 2 & 0 & 0 & 0 & 0 & 0 \\
\hline Analysis $($ ) & $\%$ & $\begin{array}{l}3 \\
\%\end{array}$ & $\begin{array}{l}4 \\
\%\end{array}$ & $\%$ & $\begin{array}{l}3 \\
\%\end{array}$ & $\%$ & $\begin{array}{l}0 \\
\%\end{array}$ & $\%$ & $\begin{array}{l}7 \\
\%\end{array}$ & $\begin{array}{l}3 \\
\%\end{array}$ & $\%$ & $\begin{array}{l}3 \\
\%\end{array}$ & $\%$ & $\%$ & $\begin{array}{l}5 \\
\%\end{array}$ & $\%$ & $\%$ & $\%$ & $\%$ & $\%$ \\
\hline ANOVA & $2 \%$ & $\begin{array}{l}0 \\
\%\end{array}$ & $\begin{array}{l}3 \\
\%\end{array}$ & $\begin{array}{l}8 \\
\%\end{array}$ & $\begin{array}{l}1 \\
\%\end{array}$ & $\begin{array}{l}0 \\
\%\end{array}$ & $\begin{array}{l}0 \\
\%\end{array}$ & $\begin{array}{l}0 \\
\%\end{array}$ & $\begin{array}{l}0 \\
\%\end{array}$ & $\begin{array}{l}0 \\
\%\end{array}$ & $\begin{array}{l}9 \\
\%\end{array}$ & $\begin{array}{l}0 \\
\%\end{array}$ & $\begin{array}{l}0 \\
\%\end{array}$ & $\begin{array}{l}0 \\
\%\end{array}$ & $\begin{array}{l}0 \\
\%\end{array}$ & $\begin{array}{l}0 \\
\%\end{array}$ & $\begin{array}{l}0 \\
\%\end{array}$ & $\begin{array}{l}0 \\
\%\end{array}$ & $\begin{array}{l}0 \\
\%\end{array}$ & $\begin{array}{l}0 \\
\%\end{array}$ \\
\hline Others & $\begin{array}{l}13 \\
\%\end{array}$ & $\begin{array}{l}1 \\
3 \\
\%\end{array}$ & $\begin{array}{l}1 \\
1 \\
\%\end{array}$ & $\begin{array}{l}1 \\
5 \\
\%\end{array}$ & $\begin{array}{l}1 \\
3 \\
\%\end{array}$ & $\begin{array}{l}18 \\
\%\end{array}$ & $\begin{array}{l}2 \\
0 \\
\%\end{array}$ & $\begin{array}{l}0 \\
\%\end{array}$ & $\begin{array}{l}1 \\
4 \\
\%\end{array}$ & $\begin{array}{l}9 \\
\%\end{array}$ & $\begin{array}{l}1 \\
8 \\
\%\end{array}$ & $\begin{array}{l}1 \\
9 \\
\%\end{array}$ & $\begin{array}{l}1 \\
7 \\
\%\end{array}$ & $\begin{array}{l}0 \\
\%\end{array}$ & $\begin{array}{l}2 \\
5 \\
\%\end{array}$ & $\begin{array}{l}0 \\
\%\end{array}$ & $\begin{array}{l}0 \\
\%\end{array}$ & $\begin{array}{l}0 \\
\%\end{array}$ & $\begin{array}{l}0 \\
\%\end{array}$ & $\begin{array}{l}0 \\
\%\end{array}$ \\
\hline No Tests & $2 \%$ & $\begin{array}{l}1 \\
\%\end{array}$ & $\begin{array}{l}3 \\
\%\end{array}$ & $\begin{array}{l}0 \\
\%\end{array}$ & $\begin{array}{l}1 \\
\%\end{array}$ & $\begin{array}{l}5 \\
\%\end{array}$ & $\begin{array}{l}0 \\
\%\end{array}$ & $\begin{array}{l}0 \\
\%\end{array}$ & $\begin{array}{l}0 \\
\%\end{array}$ & $\begin{array}{l}4 \\
\%\end{array}$ & $\begin{array}{l}0 \\
\%\end{array}$ & $\begin{array}{l}6 \\
\%\end{array}$ & $\begin{array}{l}0 \\
\%\end{array}$ & $\begin{array}{l}0 \\
\%\end{array}$ & $\begin{array}{l}0 \\
\%\end{array}$ & $\begin{array}{l}0 \\
\%\end{array}$ & $\begin{array}{l}0 \\
\%\end{array}$ & $\begin{array}{l}0 \\
\%\end{array}$ & $\begin{array}{l}0 \\
\%\end{array}$ & $\begin{array}{l}0 \\
\%\end{array}$ \\
\hline \multicolumn{21}{|l|}{ No. of Test } \\
\hline One & $\begin{array}{l}54 \\
\%\end{array}$ & $\begin{array}{l}4 \\
9 \\
\%\end{array}$ & $\begin{array}{l}5 \\
9 \\
\%\end{array}$ & $\begin{array}{l}6 \\
9 \\
\%\end{array}$ & $\begin{array}{l}5 \\
9 \\
\%\end{array}$ & $\begin{array}{l}45 \\
\%\end{array}$ & $\begin{array}{l}4 \\
0 \\
\%\end{array}$ & $\begin{array}{l}60 \\
\%\end{array}$ & $\begin{array}{l}5 \\
0 \\
\%\end{array}$ & $\begin{array}{l}6 \\
5 \\
\%\end{array}$ & $\begin{array}{l}7 \\
3 \\
\%\end{array}$ & $\begin{array}{l}4 \\
4 \\
\%\end{array}$ & $\begin{array}{l}5 \\
0 \\
\%\end{array}$ & $\begin{array}{l}0 \\
\%\end{array}$ & $\begin{array}{l}3 \\
8 \\
\%\end{array}$ & $\begin{array}{l}1 \\
0 \\
0 \\
\%\end{array}$ & $\begin{array}{l}0 \\
\%\end{array}$ & $\begin{array}{l}1 \\
0 \\
0 \\
\%\end{array}$ & $\begin{array}{l}3 \\
3 \\
\%\end{array}$ & $\begin{array}{l}1 \\
0 \\
0 \\
\%\end{array}$ \\
\hline Two & $\begin{array}{l}36 \\
\%\end{array}$ & $\begin{array}{l}3 \\
7 \\
\%\end{array}$ & $\begin{array}{l}3 \\
5 \\
\%\end{array}$ & $\begin{array}{l}3 \\
1 \\
\%\end{array}$ & $\begin{array}{l}3 \\
4 \\
\%\end{array}$ & $\begin{array}{l}41 \\
\%\end{array}$ & $\begin{array}{l}6 \\
0 \\
\%\end{array}$ & $\begin{array}{l}40 \\
\%\end{array}$ & $\begin{array}{l}3 \\
9 \\
\%\end{array}$ & $\begin{array}{l}3 \\
0 \\
\%\end{array}$ & $\begin{array}{l}2 \\
7 \\
\%\end{array}$ & $\begin{array}{l}3 \\
8 \\
\%\end{array}$ & $\begin{array}{l}5 \\
0 \\
\%\end{array}$ & $\begin{array}{l}0 \\
\%\end{array}$ & $\begin{array}{l}6 \\
3 \\
\%\end{array}$ & $\begin{array}{l}0 \\
\%\end{array}$ & $\begin{array}{l}1 \\
0 \\
0 \\
\%\end{array}$ & $\begin{array}{l}0 \\
\%\end{array}$ & $\begin{array}{l}6 \\
7 \\
\%\end{array}$ & $\begin{array}{l}0 \\
\%\end{array}$ \\
\hline Three & $8 \%$ & $\begin{array}{l}1 \\
2 \\
\%\end{array}$ & $\begin{array}{l}3 \\
\%\end{array}$ & $\begin{array}{l}0 \\
\%\end{array}$ & $\begin{array}{l}6 \\
\%\end{array}$ & $\begin{array}{l}9 \\
\%\end{array}$ & $\begin{array}{l}0 \\
\%\end{array}$ & $\begin{array}{l}0 \\
\%\end{array}$ & $\begin{array}{l}1 \\
1 \\
\%\end{array}$ & $\begin{array}{l}0 \\
\%\end{array}$ & $\begin{array}{l}0 \\
\%\end{array}$ & $\begin{array}{l}1 \\
3 \\
\%\end{array}$ & $\begin{array}{l}0 \\
\%\end{array}$ & $\begin{array}{l}0 \\
\%\end{array}$ & $\begin{array}{l}0 \\
\%\end{array}$ & $\begin{array}{l}0 \\
\%\end{array}$ & $\begin{array}{l}0 \\
\%\end{array}$ & $\begin{array}{l}0 \\
\%\end{array}$ & $\begin{array}{l}0 \\
\%\end{array}$ & $\begin{array}{l}0 \\
\%\end{array}$ \\
\hline None & $2 \%$ & $\begin{array}{l}1 \\
\%\end{array}$ & $\begin{array}{l}3 \\
\%\end{array}$ & $\begin{array}{l}0 \\
\%\end{array}$ & $\begin{array}{l}1 \\
\%\end{array}$ & $\begin{array}{l}5 \\
\%\end{array}$ & $\begin{array}{l}0 \\
\%\end{array}$ & $\begin{array}{l}0 \\
\%\end{array}$ & $\begin{array}{l}0 \\
\%\end{array}$ & $\begin{array}{l}4 \\
\%\end{array}$ & $\begin{array}{l}0 \\
\%\end{array}$ & $\begin{array}{l}6 \\
\%\end{array}$ & $\begin{array}{l}0 \\
\%\end{array}$ & $\begin{array}{l}0 \\
\%\end{array}$ & $\begin{array}{l}0 \\
\%\end{array}$ & $\begin{array}{l}0 \\
\%\end{array}$ & $\begin{array}{l}0 \\
\%\end{array}$ & $\begin{array}{l}0 \\
\%\end{array}$ & $\begin{array}{l}0 \\
\%\end{array}$ & $\begin{array}{l}0 \\
\%\end{array}$ \\
\hline
\end{tabular}




\begin{tabular}{|c|c|c|c|c|c|c|c|c|c|c|c|c|c|c|c|c|c|c|c|c|c|c|c|c|c|c|c|c|}
\hline & & \multicolumn{3}{|c|}{$\begin{array}{l}\text { By } \\
\text { Years }\end{array}$} & \multicolumn{5}{|c|}{ By Region } & \multicolumn{16}{|c|}{ By Years within Region } & \multirow{2}{*}{\multicolumn{3}{|c|}{$\begin{array}{l}\text { Asia- } \\
\text { USA }\end{array}$}} \\
\hline & & & & & & & & & & & US & & & Eur & rope & & Asi & & & & hers & & $\begin{array}{l}\text { US } \\
\text { Eur }\end{array}$ & $\begin{array}{l}\text { A- } \\
\text { rope }\end{array}$ & & & & \\
\hline & $\begin{array}{l}\mathbf{T} \\
\mathbf{o} \\
\mathbf{t} \\
\mathbf{a} \\
\mathbf{l}\end{array}$ & $\begin{array}{l}2 \\
\mathbf{0} \\
\mathbf{0} \\
\mathbf{0} \\
-\end{array}$ & $\begin{array}{l}1 \\
9 \\
9 \\
0 \\
-\end{array}$ & $\begin{array}{l}1 \\
9 \\
8 \\
0 \\
-\end{array}$ & $\begin{array}{l}\mathbf{U} \\
\mathbf{S} \\
\mathbf{A}\end{array}$ & $\begin{array}{l}\mathbf{E} \\
\mathbf{u} \\
\mathbf{r} \\
\mathbf{o} \\
\mathbf{p} \\
\mathbf{e}\end{array}$ & $\begin{array}{l}\mathbf{A} \\
\mathbf{S} \\
\mathbf{I} \\
\mathbf{A}\end{array}$ & $\begin{array}{l}\mathbf{O} \\
\mathbf{t} \\
\mathbf{h} \\
\mathbf{e} \\
\mathbf{r} \\
\mathbf{s}\end{array}$ & $\begin{array}{l}\mathbf{U} \\
\mathbf{S} \\
\mathbf{A} \\
- \\
\mathbf{E} \\
\mathbf{u} \\
\mathbf{r} \\
\mathbf{o} \\
\mathbf{p} \\
\mathbf{e}\end{array}$ & $\begin{array}{l}\mathbf{A} \\
\mathbf{s i} \\
\mathbf{a} \\
- \\
\mathbf{U} \\
\mathbf{S} \\
\mathbf{A}\end{array}$ & $\begin{array}{l}\mathbf{2} \\
\mathbf{0} \\
\mathbf{0} \\
\mathbf{0} \\
-\end{array}$ & $\begin{array}{l}\mathbf{1} \\
\mathbf{9} \\
\mathbf{9} \\
\mathbf{0} \\
-\end{array}$ & $\begin{array}{l}\mathbf{1} \\
\mathbf{9} \\
\mathbf{8} \\
\mathbf{0} \\
-\end{array}$ & $\begin{array}{l}\mathbf{2} \\
\mathbf{0} \\
\mathbf{0} \\
\mathbf{0} \\
-\end{array}$ & $\begin{array}{l}1 \\
9 \\
9 \\
0 \\
-\end{array}$ & $\begin{array}{l}1 \\
9 \\
8 \\
0 \\
-\end{array}$ & $\begin{array}{l}\mathbf{2} \\
\mathbf{0} \\
\mathbf{0} \\
\mathbf{0} \\
-\end{array}$ & $\begin{array}{l}\mathbf{1} \\
\mathbf{9} \\
\mathbf{9} \\
\mathbf{0} \\
-\end{array}$ & $\begin{array}{l}1 \\
9 \\
8 \\
0 \\
-\end{array}$ & $\begin{array}{l}\mathbf{2} \\
\mathbf{0} \\
\mathbf{0} \\
\mathbf{0} \\
-\end{array}$ & \begin{tabular}{l|}
1 \\
9 \\
9 \\
0 \\
-
\end{tabular} & \begin{tabular}{l|}
1 \\
9 \\
8 \\
0 \\
-
\end{tabular} & $\begin{array}{l}\mathbf{2} \\
\mathbf{0} \\
\mathbf{0} \\
\mathbf{0} \\
-\end{array}$ & \begin{tabular}{l|l}
1 & \\
9 & \\
9 & \\
0 & \\
- &
\end{tabular} & $\begin{array}{l}1 \\
9 \\
8 \\
0 \\
-\end{array}$ & \begin{tabular}{l|l}
$\mathbf{2}$ & \\
$\mathbf{0}$ & \\
$\mathbf{0}$ & \\
$\mathbf{0}$ & \\
- &
\end{tabular} & $\begin{array}{l}\mathbf{1} \\
\mathbf{9} \\
\mathbf{9} \\
\mathbf{0} \\
-\end{array}$ & $\begin{array}{l}1 \\
9 \\
8 \\
0 \\
-\end{array}$ \\
\hline $\begin{array}{l}\text { Total } \\
\text { Studi } \\
\text { es }\end{array}$ & \begin{tabular}{l|}
1 \\
2 \\
5 \\
\end{tabular} & $\begin{array}{l}7 \\
5\end{array}$ & $\begin{array}{l}3 \\
7\end{array}$ & $\begin{array}{l}1 \\
3\end{array}$ & $\begin{array}{l}7 \\
0\end{array}$ & $\begin{array}{l}2 \\
2\end{array}$ & $\begin{array}{l}1 \\
0\end{array}$ & 5 & 5 & 6 & $\begin{array}{l}3 \\
6\end{array}$ & $\begin{array}{l}2 \\
3\end{array}$ & $\begin{array}{l}1 \\
1\end{array}$ & $\begin{array}{l}1 \\
6\end{array}$ & 6 & 0 & 8 & 1 & 3 & 1 & 3 & 1 & 3 & 2 & 0 & 5 & 1 & 0 \\
\hline $\begin{array}{l}\text { Autho } \\
\text { rship- } \\
\text { Type }\end{array}$ & & & & & & & & & & & & & & & & & & & & & & & & & & & & \\
\hline $\begin{array}{l}\text { Acade } \\
\text { mics }\end{array}$ & $\begin{array}{l}1 \\
8 \\
8 \\
\% \\
\end{array}$ & \begin{tabular}{l|}
1 \\
8 \\
9 \\
$\%$ \\
\end{tabular} & $\begin{array}{l}1 \\
9 \\
2 \\
\%\end{array}$ & \begin{tabular}{l|}
1 \\
6 \\
9 \\
$\%$
\end{tabular} & \begin{tabular}{l|}
1 \\
8 \\
3 \\
$\%$ \\
\end{tabular} & $\begin{array}{l}1 \\
7 \\
7 \\
\% \\
\end{array}$ & $\begin{array}{l}2 \\
3 \\
0 \\
\% \\
\end{array}$ & $\begin{array}{l}2 \\
2 \\
0 \\
\% \\
\end{array}$ & $\begin{array}{l}2 \\
4 \\
0 \\
\%\end{array}$ & $\begin{array}{l}2 \\
3 \\
0 \\
\% \\
\end{array}$ & $\begin{array}{l}1 \\
8 \\
3 \\
\%\end{array}$ & \begin{tabular}{l|}
1 \\
9 \\
6 \\
$\%$
\end{tabular} & \begin{tabular}{l|}
1 \\
5 \\
5 \\
$\%$ \\
\end{tabular} & \begin{tabular}{l|}
1 \\
8 \\
1 \\
$\%$ \\
\end{tabular} & \begin{tabular}{l|}
1 \\
6 \\
7 \\
$\%$ \\
\end{tabular} & $\begin{array}{l}0 \\
\%\end{array}$ & $\begin{array}{l}2 \\
2 \\
5 \\
\% \\
\end{array}$ & \begin{tabular}{l|}
2 \\
0 \\
0 \\
$\%$ \\
\end{tabular} & $\begin{array}{l}1 \\
0 \\
0 \\
\%\end{array}$ & \begin{tabular}{l|}
3 \\
0 \\
0 \\
$\%$ \\
\end{tabular} & \begin{tabular}{l|}
2 \\
0 \\
0 \\
$\%$ \\
\end{tabular} & \begin{tabular}{l|}
2 \\
0 \\
0 \\
$\%$ \\
\end{tabular} & $\begin{array}{l}2 \\
6 \\
7 \\
\% \\
\end{array}$ & $\begin{array}{l}2 \\
0 \\
0 \\
\%\end{array}$ & $\begin{array}{l}0 \\
\%\end{array}$ & \begin{tabular}{l|l}
2 & \\
0 & \\
0 & \\
$\%$ & \\
\end{tabular} & $\begin{array}{l}2 \\
0 \\
0 \\
\% \\
\end{array}$ & $\begin{array}{l}0 \\
\%\end{array}$ \\
\hline $\begin{array}{l}\text { Practi } \\
\text { oners }\end{array}$ & $\begin{array}{l}1 \\
0 \\
\%\end{array}$ & \begin{tabular}{l|}
7 \\
$\%$
\end{tabular} & \begin{tabular}{l|}
1 \\
1 \\
$\%$
\end{tabular} & \begin{tabular}{l|}
3 \\
1 \\
$\%$
\end{tabular} & \begin{tabular}{l|l}
1 \\
7 \\
$\%$
\end{tabular} & $\begin{array}{l}0 \\
\%\end{array}$ & \begin{tabular}{l|l}
0 \\
$\%$
\end{tabular} & $\begin{array}{l}0 \\
\%\end{array}$ & $\begin{array}{l}0 \\
\%\end{array}$ & $\begin{array}{l}0 \\
\%\end{array}$ & $\begin{array}{l}1 \\
1 \\
\%\end{array}$ & \begin{tabular}{l|}
1 \\
7 \\
$\%$
\end{tabular} & \begin{tabular}{l|}
3 \\
6 \\
$\%$ \\
\end{tabular} & \begin{tabular}{l|l}
0 \\
$\%$
\end{tabular} & $\begin{array}{l}0 \\
\%\end{array}$ & \begin{tabular}{l|}
0 \\
$\%$
\end{tabular} & \begin{tabular}{l|}
0 \\
$\%$
\end{tabular} & $\begin{array}{l}0 \\
\%\end{array}$ & $\begin{array}{l}0 \\
\%\end{array}$ & $\begin{array}{l}0 \\
\%\end{array}$ & $\begin{array}{l}0 \\
\%\end{array}$ & $\begin{array}{l}0 \\
\%\end{array}$ & $\begin{array}{l}0 \\
\%\end{array}$ & $\begin{array}{l}0 \\
\%\end{array}$ & \begin{tabular}{l|l}
0 & \\
$\%$ &
\end{tabular} & \begin{tabular}{l|l}
2 & \\
0 & \\
$\%$ &
\end{tabular} & $\begin{array}{l}0 \\
\%\end{array}$ & $\begin{array}{l}0 \\
\%\end{array}$ \\
\hline $\begin{array}{l}\text { Acad./ } \\
\text { Practi } \\
\text { oner } \\
\text { (Colla } \\
\text { borati } \\
\text { on) }\end{array}$ & $\begin{array}{l}1 \\
0 \\
\%\end{array}$ & \begin{tabular}{l|}
5 \\
$\%$
\end{tabular} & \begin{tabular}{l|}
1 \\
1 \\
$\%$
\end{tabular} & \begin{tabular}{l|}
3 \\
1 \\
$\%$
\end{tabular} & \begin{tabular}{l|}
1 \\
6 \\
$\%$
\end{tabular} & $\begin{array}{l}0 \\
\%\end{array}$ & \begin{tabular}{l|}
0 \\
$\%$
\end{tabular} & $\begin{array}{l}0 \\
\%\end{array}$ & $\begin{array}{l}0 \\
\%\end{array}$ & $\begin{array}{l}0 \\
\%\end{array}$ & $\begin{array}{l}0 \\
\%\end{array}$ & \begin{tabular}{l|}
1 \\
7 \\
$\%$
\end{tabular} & \begin{tabular}{l|}
3 \\
6 \\
$\%$
\end{tabular} & $\begin{array}{l}0 \\
\%\end{array}$ & $\begin{array}{l}0 \\
\%\end{array}$ & $\begin{array}{l}0 \\
\%\end{array}$ & $\begin{array}{l}0 \\
\%\end{array}$ & \begin{tabular}{l|}
0 \\
$\%$
\end{tabular} & $\begin{array}{l}0 \\
\%\end{array}$ & $\begin{array}{l}0 \\
\%\end{array}$ & $\begin{array}{l}0 \\
\%\end{array}$ & $\begin{array}{l}0 \\
\%\end{array}$ & \begin{tabular}{l|}
0 \\
$\%$
\end{tabular} & $\begin{array}{l}0 \\
\%\end{array}$ & \begin{tabular}{l|l}
0 \\
$\%$
\end{tabular} & \begin{tabular}{l|l|}
0 \\
$\%$
\end{tabular} & \begin{tabular}{l|}
0 \\
$\%$
\end{tabular} & $\begin{array}{l}0 \\
\%\end{array}$ \\
\hline
\end{tabular}

\section{Autho}

rship-

Colla

borati

on

\begin{tabular}{l|l|l|l|l|l|l|l|l|l|l|l|l|l|l|l|l|l|l|l|l|l|l|l|l|l|l|l|l|}
\hline Multi & 1 & 1 & 1 & 0 & 0 & 1 & 0 & 4 & 1 & 0 & 0 & 0 & 0 & 1 & 1 & 0 & 0 & 0 & 0 & 1 & 3 & 0 & 1 & 1 & 0 & 1 & 1 & 0
\end{tabular}

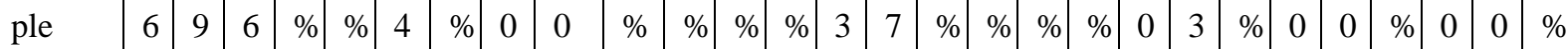

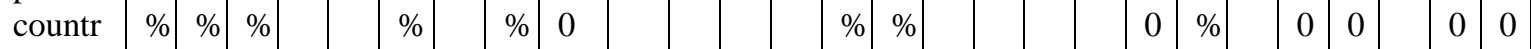

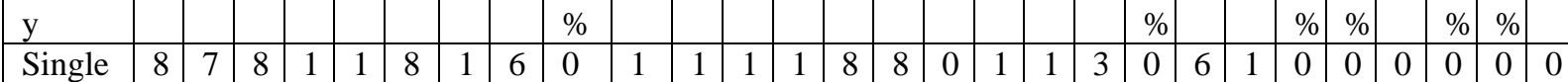
$\begin{array}{lllllllllllllllllllllllllllllllllll}\text { countr } & 2 & 7 & 4 & 0 & 0 & 6 & 0 & 0 & \% & 0 & 0 & 0 & 0 & 8 & 3 & \% & 0 & 0 & 3 & \% & 7 & 0 & \% & \% & \% & \% & \% & \%\end{array}$ \begin{tabular}{l|lllllllllllllllllll|l|l|l|l|l|l|l}
$\mathrm{y}$ & $\%$ & $\%$ & $\%$ & 0 & 0 & $\%$ & 0 & $\%$ & & 0 & 0 & 0 & 0 & $\%$ & $\%$ & & 0 & 0 & $\%$ & $\%$ & 0
\end{tabular}

\section{Autho}

rship-

Per

Study

\begin{tabular}{l|l|l|l|l|l|l|l|l|l|l|l|l|l|l|l|l|l|l|l|l|l|l|l|l|l|l|l|l|}
\hline Single & 2 & 2 & 2 & 3 & 2 & 5 & 3 & 6 & 0 & 3 & 2 & 1 & 2 & 5 & 5 & 0 & 2 & 1 & 0 & 0 & 6 & 1 & 0 & 0 & 0 & 0 & 0 & 0
\end{tabular} $\begin{array}{llllllllllllllllllllllllllllllllllll}\text { Autho } & 7 & 8 & 4 & 1 & 3 & 0 & 0 & 0 & \% & 0 & 8 & 3 & 7 & 0 & 0 & \% & 5 & 0 & \% & \% & 7 & 0 & \% & \% & \% & \% & \% & \%\end{array}$

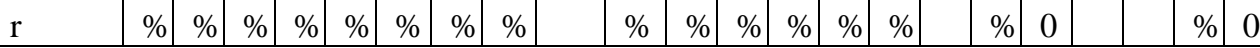




\begin{tabular}{|c|c|c|c|c|c|c|c|c|c|c|c|c|c|c|c|c|c|c|c|c|c|c|c|c|c|c|c|c|}
\hline & & & & & & & & & & & & & & & & & & $\%$ & & & & $\%$ & & & & & & \\
\hline $\begin{array}{l}\text { Two } \\
\text { Autho } \\
r\end{array}$ & \begin{tabular}{l|}
4 \\
6 \\
$\%$
\end{tabular} & $\begin{array}{l}4 \\
1 \\
\%\end{array}$ & $\begin{array}{l}5 \\
7 \\
\%\end{array}$ & \begin{tabular}{l|}
4 \\
6 \\
$\%$
\end{tabular} & \begin{tabular}{l|}
5 \\
6 \\
$\%$
\end{tabular} & $\begin{array}{l}2 \\
7 \\
\%\end{array}$ & \begin{tabular}{l|}
2 \\
0 \\
$\%$ \\
\end{tabular} & $\begin{array}{l}2 \\
0 \\
\%\end{array}$ & $\begin{array}{l}6 \\
0 \\
\%\end{array}$ & $\begin{array}{l}2 \\
0 \\
\%\end{array}$ & $\begin{array}{l}5 \\
0 \\
\%\end{array}$ & $\begin{array}{l}6 \\
5 \\
\%\end{array}$ & $\begin{array}{l}5 \\
5 \\
\%\end{array}$ & $\begin{array}{l}2 \\
5 \\
\%\end{array}$ & \begin{tabular}{l|}
3 \\
3 \\
$\%$
\end{tabular} & \begin{tabular}{|l|}
0 \\
$\%$ \\
\end{tabular} & $\begin{array}{l}2 \\
5 \\
\%\end{array}$ & \begin{tabular}{|l|}
0 \\
$\%$
\end{tabular} & $\begin{array}{l}0 \\
\%\end{array}$ & $\begin{array}{l}0 \\
\%\end{array}$ & \begin{tabular}{l|}
3 \\
3 \\
$\%$
\end{tabular} & $\begin{array}{l}0 \\
\%\end{array}$ & \begin{tabular}{l|}
3 \\
3 \\
$\%$
\end{tabular} & \begin{tabular}{l|}
1 \\
0 \\
0 \\
$\%$
\end{tabular} & $\begin{array}{l}0 \\
\%\end{array}$ & \begin{tabular}{l|}
8 \\
0 \\
$\%$
\end{tabular} & \begin{tabular}{l|}
1 \\
0 \\
0 \\
$\%$
\end{tabular} & $\begin{array}{l}0 \\
\%\end{array}$ \\
\hline $\begin{array}{l}\text { Three } \\
\text { Autho } \\
\text { r }\end{array}$ & $\begin{array}{l}2 \\
4 \\
\%\end{array}$ & $\begin{array}{l}2 \\
8 \\
\%\end{array}$ & $\begin{array}{l}1 \\
6 \\
\%\end{array}$ & \begin{tabular}{l|}
2 \\
3 \\
$\%$
\end{tabular} & $\begin{array}{l}1 \\
9 \\
\%\end{array}$ & $\begin{array}{l}1 \\
8 \\
\%\end{array}$ & \begin{tabular}{|l|}
5 \\
0 \\
$\%$ \\
\end{tabular} & $\begin{array}{l}2 \\
0 \\
\%\end{array}$ & $\begin{array}{l}4 \\
0 \\
\%\end{array}$ & $\begin{array}{l}5 \\
0 \\
\%\end{array}$ & $\begin{array}{l}1 \\
9 \\
\%\end{array}$ & $\begin{array}{l}1 \\
7 \\
\%\end{array}$ & $\begin{array}{l}1 \\
8 \\
\%\end{array}$ & $\begin{array}{l}1 \\
9 \\
\%\end{array}$ & $\begin{array}{l}1 \\
7 \\
\%\end{array}$ & \begin{tabular}{|l|}
0 \\
$\%$
\end{tabular} & $\begin{array}{l}5 \\
0 \\
\%\end{array}$ & \begin{tabular}{l|}
0 \\
$\%$
\end{tabular} & \begin{tabular}{l|}
3 \\
3 \\
$\%$
\end{tabular} & $\begin{array}{l}1 \\
0 \\
0 \\
\%\end{array}$ & $\begin{array}{l}0 \\
\%\end{array}$ & $\begin{array}{l}0 \\
\%\end{array}$ & \begin{tabular}{l|}
6 \\
7 \\
$\%$
\end{tabular} & $\begin{array}{l}0 \\
\%\end{array}$ & $\begin{array}{l}0 \\
\%\end{array}$ & $\begin{array}{l}2 \\
0 \\
\%\end{array}$ & $\begin{array}{l}0 \\
\%\end{array}$ & $\begin{array}{l}0 \\
\%\end{array}$ \\
\hline $\begin{array}{l}\text { Four } \\
\text { Autho } \\
\text { r }\end{array}$ & $\begin{array}{l}2 \\
\%\end{array}$ & $\begin{array}{l}3 \\
\%\end{array}$ & $\begin{array}{l}3 \\
\%\end{array}$ & $\begin{array}{l}0 \\
\%\end{array}$ & $\begin{array}{l}3 \\
\%\end{array}$ & $\begin{array}{l}5 \\
\%\end{array}$ & \begin{tabular}{l|}
0 \\
$\%$
\end{tabular} & $\begin{array}{l}0 \\
\%\end{array}$ & $\begin{array}{l}0 \\
\%\end{array}$ & $\begin{array}{l}0 \\
\%\end{array}$ & $\begin{array}{l}3 \\
\%\end{array}$ & $\begin{array}{l}4 \\
\%\end{array}$ & $\begin{array}{l}0 \\
\%\end{array}$ & $\begin{array}{l}6 \\
\%\end{array}$ & $\begin{array}{l}0 \\
\%\end{array}$ & \begin{tabular}{l|}
0 \\
$\%$ \\
\end{tabular} & $\begin{array}{l}0 \\
\%\end{array}$ & \begin{tabular}{|l|}
0 \\
$\%$
\end{tabular} & $\begin{array}{l}0 \\
\%\end{array}$ & $\begin{array}{l}0 \\
\%\end{array}$ & $\begin{array}{l}0 \\
\%\end{array}$ & $\begin{array}{l}0 \\
\%\end{array}$ & $\begin{array}{l}0 \\
\%\end{array}$ & $\begin{array}{l}0 \\
\%\end{array}$ & $\begin{array}{l}0 \\
\%\end{array}$ & $\begin{array}{l}0 \\
\%\end{array}$ & $\begin{array}{l}0 \\
\%\end{array}$ & $\begin{array}{l}0 \\
\%\end{array}$ \\
\hline $\begin{array}{l}\text { Journ } \\
\text { als } \\
\text { Ratin } \\
\text { gs(Hi } \\
\text { ghest } \\
\text { Publi } \\
\text { cation } \\
\text { s) }\end{array}$ & & & & & & & & & & & & & & & & & & & & & & & & & & & & \\
\hline $\mathrm{A}^{*}$ & \begin{tabular}{l|}
6 \\
7 \\
$\%$
\end{tabular} & \begin{tabular}{l|}
3 \\
2 \\
$\%$
\end{tabular} & $\begin{array}{l}4 \\
1 \\
\%\end{array}$ & $\begin{array}{l}6 \\
2 \\
\%\end{array}$ & $\begin{array}{l}4 \\
0 \\
\%\end{array}$ & \begin{tabular}{l|}
1 \\
8 \\
$\%$
\end{tabular} & \begin{tabular}{|l|}
4 \\
0 \\
$\%$ \\
\end{tabular} & $\begin{array}{l}6 \\
0 \\
\%\end{array}$ & $\begin{array}{l}4 \\
0 \\
\%\end{array}$ & $\begin{array}{l}4 \\
0 \\
\%\end{array}$ & \begin{tabular}{l|}
3 \\
1 \\
$\%$
\end{tabular} & $\begin{array}{l}4 \\
8 \\
\%\end{array}$ & $\begin{array}{l}5 \\
5 \\
\%\end{array}$ & $\begin{array}{l}2 \\
5 \\
\%\end{array}$ & $\begin{array}{l}0 \\
\%\end{array}$ & \begin{tabular}{|l|}
0 \\
$\%$
\end{tabular} & \begin{tabular}{l|}
3 \\
8 \\
$\%$
\end{tabular} & $\begin{array}{l}0 \\
\%\end{array}$ & \begin{tabular}{l|}
3 \\
3 \\
$\%$
\end{tabular} & $\begin{array}{l}0 \\
\%\end{array}$ & \begin{tabular}{l|}
6 \\
7 \\
$\%$
\end{tabular} & \begin{tabular}{l|l}
1 \\
0 \\
0 \\
$\%$
\end{tabular} & \begin{tabular}{l|}
3 \\
3 \\
$\%$
\end{tabular} & \begin{tabular}{l|}
5 \\
0 \\
$\%$
\end{tabular} & $\begin{array}{l}0 \\
\%\end{array}$ & $\begin{array}{l}8 \\
0 \\
\%\end{array}$ & $\begin{array}{l}1 \\
0 \\
0 \\
\%\end{array}$ & $\begin{array}{l}0 \\
\%\end{array}$ \\
\hline A & $\begin{array}{l}3 \\
0 \\
\%\end{array}$ & $\begin{array}{l}3 \\
5 \\
\%\end{array}$ & $\begin{array}{l}1 \\
9 \\
\%\end{array}$ & \begin{tabular}{l|}
3 \\
1 \\
$\%$
\end{tabular} & \begin{tabular}{l|}
3 \\
0 \\
$\%$
\end{tabular} & \begin{tabular}{l|}
3 \\
6 \\
$\%$
\end{tabular} & \begin{tabular}{|l|}
2 \\
0 \\
$\%$ \\
\end{tabular} & $\begin{array}{l}2 \\
0 \\
\%\end{array}$ & $\begin{array}{l}2 \\
0 \\
\%\end{array}$ & \begin{tabular}{l|}
2 \\
0 \\
$\%$
\end{tabular} & \begin{tabular}{l|}
3 \\
6 \\
$\%$
\end{tabular} & \begin{tabular}{l|}
1 \\
7 \\
$\%$
\end{tabular} & \begin{tabular}{l|}
3 \\
6 \\
$\%$
\end{tabular} & $\begin{array}{l}3 \\
8 \\
\%\end{array}$ & \begin{tabular}{l|}
3 \\
3 \\
$\%$
\end{tabular} & \begin{tabular}{|l|}
0 \\
$\%$
\end{tabular} & $\begin{array}{l}2 \\
5 \\
\%\end{array}$ & $\begin{array}{l}0 \\
\%\end{array}$ & $\begin{array}{l}0 \\
\%\end{array}$ & $\begin{array}{l}1 \\
0 \\
0 \\
\%\end{array}$ & $\begin{array}{l}0 \\
\%\end{array}$ & \begin{tabular}{l|}
0 \\
$\%$
\end{tabular} & \begin{tabular}{l|}
3 \\
3 \\
$\%$
\end{tabular} & $\begin{array}{l}0 \\
\%\end{array}$ & $\begin{array}{l}0 \\
\%\end{array}$ & \begin{tabular}{l|}
2 \\
0 \\
$\%$
\end{tabular} & $\begin{array}{l}0 \\
\%\end{array}$ & $\begin{array}{l}0 \\
\%\end{array}$ \\
\hline B & \begin{tabular}{l|}
1 \\
3 \\
$\%$ \\
\end{tabular} & $\begin{array}{l}1 \\
1 \\
\% \\
\end{array}$ & $\begin{array}{l}2 \\
2 \\
\% \\
\end{array}$ & $\begin{array}{l}0 \\
\%\end{array}$ & \begin{tabular}{l|}
1 \\
4 \\
$\%$ \\
\end{tabular} & $\begin{array}{l}1 \\
4 \\
\% \\
\end{array}$ & \begin{tabular}{l|}
0 \\
$\%$
\end{tabular} & $\begin{array}{l}0 \\
\%\end{array}$ & $\begin{array}{l}2 \\
0 \\
\% \\
\end{array}$ & $\begin{array}{l}0 \\
\%\end{array}$ & $\begin{array}{l}1 \\
1 \\
\% \\
\end{array}$ & $\begin{array}{l}2 \\
6 \\
\% \\
\end{array}$ & $\begin{array}{l}0 \\
\%\end{array}$ & $\begin{array}{l}1 \\
3 \\
\% \\
\end{array}$ & $\begin{array}{l}1 \\
7 \\
\% \\
\end{array}$ & \begin{tabular}{|l|}
0 \\
$\%$
\end{tabular} & $\begin{array}{l}0 \\
\%\end{array}$ & $\begin{array}{l}0 \\
\%\end{array}$ & \begin{tabular}{l|}
0 \\
$\%$
\end{tabular} & $\begin{array}{l}0 \\
\%\end{array}$ & $\begin{array}{l}0 \\
\%\end{array}$ & \begin{tabular}{l|l}
0 \\
$\%$
\end{tabular} & \begin{tabular}{l|}
0 \\
$\%$
\end{tabular} & \begin{tabular}{l|}
5 \\
0 \\
$\%$ \\
\end{tabular} & $\begin{array}{l}0 \\
\%\end{array}$ & $\begin{array}{l}0 \\
\%\end{array}$ & $\begin{array}{l}0 \\
\%\end{array}$ & $\begin{array}{l}0 \\
\%\end{array}$ \\
\hline $\mathrm{C}$ & $\begin{array}{l}6 \\
\%\end{array}$ & $\begin{array}{l}7 \\
\%\end{array}$ & $\begin{array}{l}5 \\
\%\end{array}$ & $\begin{array}{l}0 \\
\%\end{array}$ & $\begin{array}{l}4 \\
\%\end{array}$ & $\begin{array}{l}1 \\
4 \\
\%\end{array}$ & \begin{tabular}{l|}
1 \\
0 \\
$\%$ \\
\end{tabular} & $\begin{array}{l}0 \\
\%\end{array}$ & $\begin{array}{l}0 \\
\%\end{array}$ & $\begin{array}{l}1 \\
0 \\
\%\end{array}$ & $\begin{array}{l}8 \\
\%\end{array}$ & $\begin{array}{l}0 \\
\%\end{array}$ & $\begin{array}{l}0 \\
\%\end{array}$ & $\begin{array}{l}1 \\
3 \\
\%\end{array}$ & $\begin{array}{l}1 \\
7 \\
\%\end{array}$ & \begin{tabular}{|l|}
0 \\
$\%$
\end{tabular} & $\begin{array}{l}0 \\
\%\end{array}$ & $\begin{array}{l}1 \\
0 \\
0 \\
\% \\
\end{array}$ & \begin{tabular}{l|}
0 \\
$\%$
\end{tabular} & $\begin{array}{l}0 \\
\%\end{array}$ & $\begin{array}{l}0 \\
\%\end{array}$ & \begin{tabular}{l|l}
0 \\
$\%$
\end{tabular} & \begin{tabular}{l|}
0 \\
$\%$
\end{tabular} & \begin{tabular}{l|}
0 \\
$\%$
\end{tabular} & $\begin{array}{l}0 \\
\%\end{array}$ & $\begin{array}{l}0 \\
\%\end{array}$ & $\begin{array}{l}0 \\
\%\end{array}$ & $\begin{array}{l}0 \\
\%\end{array}$ \\
\hline $\begin{array}{l}\text { Not } \\
\text { given }\end{array}$ & $\begin{array}{l}1 \\
4 \\
\%\end{array}$ & $\begin{array}{l}1 \\
6 \\
\%\end{array}$ & $\begin{array}{l}1 \\
4 \\
\%\end{array}$ & $\begin{array}{l}0 \\
\%\end{array}$ & \begin{tabular}{l|}
1 \\
1 \\
$\%$
\end{tabular} & $\begin{array}{l}1 \\
8 \\
\%\end{array}$ & \begin{tabular}{l|}
3 \\
0 \\
$\%$ \\
\end{tabular} & $\begin{array}{l}2 \\
0 \\
\%\end{array}$ & $\begin{array}{l}2 \\
0 \\
\%\end{array}$ & $\begin{array}{l}3 \\
0 \\
\%\end{array}$ & $\begin{array}{l}1 \\
4 \\
\%\end{array}$ & $\begin{array}{l}9 \\
\%\end{array}$ & $\begin{array}{l}0 \\
\%\end{array}$ & $\begin{array}{l}1 \\
3 \\
\%\end{array}$ & $\begin{array}{l}3 \\
3 \\
\% \\
\end{array}$ & \begin{tabular}{|l|}
0 \\
$\%$ \\
\end{tabular} & $\begin{array}{l}3 \\
8 \\
\% \\
\end{array}$ & $\begin{array}{l}0 \\
\%\end{array}$ & $\begin{array}{l}0 \\
\%\end{array}$ & $\begin{array}{l}0 \\
\%\end{array}$ & \begin{tabular}{l|}
3 \\
3 \\
$\%$
\end{tabular} & \begin{tabular}{l|l}
0 \\
$\%$
\end{tabular} & \begin{tabular}{l|}
3 \\
3 \\
$\%$
\end{tabular} & $\begin{array}{l}0 \\
\%\end{array}$ & $\begin{array}{l}0 \\
\%\end{array}$ & $\begin{array}{l}0 \\
\%\end{array}$ & $\begin{array}{l}0 \\
\%\end{array}$ & $\begin{array}{l}0 \\
\%\end{array}$ \\
\hline $\begin{array}{l}\text { Discip } \\
\text { line }\end{array}$ & & & & & & & & & & & & & & & & & & & & & & & & & & & & \\
\hline $\begin{array}{l}\text { Econo } \\
\text { mics }\end{array}$ & $\begin{array}{l}2 \\
1 \\
\%\end{array}$ & $\begin{array}{l}1 \\
9 \\
\%\end{array}$ & $\begin{array}{l}2 \\
2 \\
\%\end{array}$ & $\begin{array}{l}3 \\
1 \\
\%\end{array}$ & $\begin{array}{l}1 \\
6 \\
\%\end{array}$ & $\begin{array}{l}2 \\
7 \\
\%\end{array}$ & \begin{tabular}{|l|}
3 \\
0 \\
$\%$ \\
\end{tabular} & $\begin{array}{l}6 \\
0 \\
\%\end{array}$ & $\begin{array}{l}0 \\
\%\end{array}$ & $\begin{array}{l}3 \\
0 \\
\%\end{array}$ & $\begin{array}{l}1 \\
4 \\
\%\end{array}$ & $\begin{array}{l}1 \\
3 \\
\%\end{array}$ & $\begin{array}{l}2 \\
7 \\
\%\end{array}$ & $\begin{array}{l}2 \\
5 \\
\%\end{array}$ & $\begin{array}{l}3 \\
3 \\
\%\end{array}$ & \begin{tabular}{|l|}
0 \\
$\%$
\end{tabular} & $\begin{array}{l}2 \\
5 \\
\%\end{array}$ & $\begin{array}{l}1 \\
0 \\
0 \\
\%\end{array}$ & $\begin{array}{l}0 \\
\%\end{array}$ & $\begin{array}{l}0 \\
\%\end{array}$ & $\begin{array}{l}6 \\
7 \\
\%\end{array}$ & \begin{tabular}{l|}
1 \\
0 \\
0 \\
$\%$
\end{tabular} & $\begin{array}{l}0 \\
\%\end{array}$ & $\begin{array}{l}0 \\
\%\end{array}$ & $\begin{array}{l}0 \\
\%\end{array}$ & $\begin{array}{l}4 \\
0 \\
\%\end{array}$ & $\begin{array}{l}0 \\
\%\end{array}$ & $\begin{array}{l}0 \\
\%\end{array}$ \\
\hline Entrep & $\begin{array}{l}4 \\
\%\end{array}$ & $\begin{array}{l}5 \\
\% \\
\end{array}$ & $\begin{array}{l}3 \\
\% \\
\end{array}$ & \begin{tabular}{l|}
0 \\
$\%$ \\
\end{tabular} & $\begin{array}{l}6 \\
\% \\
\end{array}$ & $\begin{array}{l}5 \\
\% \\
\end{array}$ & \begin{tabular}{|l|}
0 \\
$\%$ \\
\end{tabular} & $\begin{array}{l}0 \\
\% \\
\end{array}$ & $\begin{array}{l}0 \\
\% \\
\end{array}$ & $\begin{array}{l}0 \\
\% \\
\end{array}$ & $\begin{array}{l}8 \\
\% \\
\end{array}$ & $\begin{array}{l}4 \\
\% \\
\end{array}$ & $\begin{array}{l}0 \\
\% \\
\end{array}$ & $\begin{array}{l}6 \\
\% \\
\end{array}$ & $\begin{array}{l}0 \\
\% \\
\end{array}$ & \begin{tabular}{|l|}
0 \\
$\%$ \\
\end{tabular} & $\begin{array}{l}0 \\
\% \\
\end{array}$ & \begin{tabular}{|l|}
0 \\
$\%$ \\
\end{tabular} & \begin{tabular}{l|}
0 \\
$\%$
\end{tabular} & \begin{tabular}{l|}
0 \\
$\%$
\end{tabular} & \begin{tabular}{l|}
0 \\
$\%$
\end{tabular} & \begin{tabular}{l|}
0 \\
$\%$
\end{tabular} & \begin{tabular}{l|l}
0 \\
$\%$
\end{tabular} & \begin{tabular}{l|l}
0 \\
$\%$
\end{tabular} & \begin{tabular}{l|}
0 \\
$\%$
\end{tabular} & \begin{tabular}{l|}
0 \\
$\%$
\end{tabular} & \begin{tabular}{l|}
0 \\
$\%$ \\
\end{tabular} & $\begin{array}{l}0 \\
\% \\
\end{array}$ \\
\hline$F \& A$ & $\begin{array}{l}4 \\
5 \\
\%\end{array}$ & $\begin{array}{l}4 \\
3 \\
\%\end{array}$ & $\begin{array}{l}4 \\
6 \\
\%\end{array}$ & $\begin{array}{l}5 \\
4 \\
\%\end{array}$ & $\begin{array}{l}4 \\
9 \\
\%\end{array}$ & $\begin{array}{l}4 \\
1 \\
\%\end{array}$ & \begin{tabular}{|l|}
2 \\
0 \\
$\%$
\end{tabular} & $\begin{array}{l}2 \\
0 \\
\%\end{array}$ & $\begin{array}{l}6 \\
0 \\
\%\end{array}$ & $\begin{array}{l}2 \\
0 \\
\%\end{array}$ & $\begin{array}{l}4 \\
4 \\
\%\end{array}$ & $\begin{array}{l}5 \\
2 \\
\%\end{array}$ & $\begin{array}{l}5 \\
5 \\
\%\end{array}$ & $\begin{array}{l}4 \\
4 \\
\%\end{array}$ & $\begin{array}{l}3 \\
3 \\
\%\end{array}$ & \begin{tabular}{|l|}
0 \\
$\%$
\end{tabular} & $\begin{array}{l}1 \\
3 \\
\%\end{array}$ & \begin{tabular}{l|}
0 \\
$\%$
\end{tabular} & $\begin{array}{l}3 \\
3 \\
\%\end{array}$ & $\begin{array}{l}1 \\
0 \\
0 \\
\%\end{array}$ & $\begin{array}{l}0 \\
\%\end{array}$ & $\begin{array}{l}0 \\
\%\end{array}$ & $\begin{array}{l}6 \\
7 \\
\%\end{array}$ & $\begin{array}{l}5 \\
0 \\
\%\end{array}$ & $\begin{array}{l}0 \\
\%\end{array}$ & $\begin{array}{l}4 \\
0 \\
\%\end{array}$ & $\begin{array}{l}1 \\
0 \\
0 \\
\%\end{array}$ & $\begin{array}{l}0 \\
\%\end{array}$ \\
\hline $\begin{array}{l}\text { Genr } \\
\& \\
\text { Strat }\end{array}$ & $\begin{array}{l}1 \\
0 \\
\%\end{array}$ & \begin{tabular}{l|}
1 \\
1 \\
$\%$
\end{tabular} & $\begin{array}{l}1 \\
4 \\
\%\end{array}$ & $\begin{array}{l}0 \\
\%\end{array}$ & \begin{tabular}{l|}
1 \\
3 \\
$\%$
\end{tabular} & $\begin{array}{l}9 \\
\%\end{array}$ & \begin{tabular}{l|}
0 \\
$\%$ \\
\end{tabular} & $\begin{array}{l}0 \\
\%\end{array}$ & $\begin{array}{l}2 \\
0 \\
\%\end{array}$ & $\begin{array}{l}0 \\
\%\end{array}$ & $\begin{array}{l}1 \\
4 \\
\%\end{array}$ & $\begin{array}{l}1 \\
7 \\
\%\end{array}$ & $\begin{array}{l}0 \\
\%\end{array}$ & $\begin{array}{l}1 \\
3 \\
\%\end{array}$ & $\begin{array}{l}0 \\
\% \\
\end{array}$ & \begin{tabular}{|l|}
0 \\
$\%$
\end{tabular} & $\begin{array}{l}0 \\
\%\end{array}$ & \begin{tabular}{|l|}
0 \\
$\%$
\end{tabular} & \begin{tabular}{l|}
0 \\
$\%$
\end{tabular} & \begin{tabular}{l|l}
0 \\
$\%$
\end{tabular} & \begin{tabular}{l|}
0 \\
$\%$
\end{tabular} & \begin{tabular}{l|}
0 \\
$\%$
\end{tabular} & \begin{tabular}{l|l}
0 \\
$\%$
\end{tabular} & \begin{tabular}{l|}
5 \\
0 \\
$\%$
\end{tabular} & \begin{tabular}{l|}
0 \\
$\%$
\end{tabular} & \begin{tabular}{l|}
2 \\
0 \\
$\%$
\end{tabular} & $\begin{array}{l}0 \\
\%\end{array}$ & $\begin{array}{l}0 \\
\%\end{array}$ \\
\hline
\end{tabular}


Mehreen et al. / Publication Trends and Methodological Advancements

\begin{tabular}{|l|l|l|l|l|l|l|l|l|l|l|l|l|l|l|l|l|l|l|l|l|l|l|l|l|l|l|l|l|}
\hline $\begin{array}{l}\text { Marke } \\
\text { ting }\end{array}$ & $\begin{array}{l}3 \\
\%\end{array}$ & 4 & 3 & 0 & 3 & 0 & 2 & 0 & 0 & 2 & 3 & 4 & 0 & 0 & 0 & 0 & 2 & 0 & 0 & 0 & 0 & 0 & 0 & 0 & 0 & 0 & 0 & 0 \\
& & & & & & $\%$ & $\%$ & 0 & $\%$ & $\%$ & $\%$ & $\%$ & $\%$ & $\%$ & 5 & $\%$ & $\%$ & $\%$ & $\%$ & $\%$ & $\%$ & $\%$ & $\%$ & $\%$ & $\%$ & $\%$ \\
\hline Others & 2 & 3 & 0 & 8 & 3 & 5 & 0 & 0 & 0 & 0 & 3 & 0 & 9 & 6 & 0 & 0 & 0 & 0 & 0 & 0 & 0 & 0 & 0 & 0 & 0 & 0 & 0 & 0 \\
& $\%$ & $\%$ & $\%$ & $\%$ & $\%$ & $\%$ & $\%$ & $\%$ & $\%$ & $\%$ & $\%$ & $\%$ & $\%$ & $\%$ & $\%$ & $\%$ & $\%$ & $\%$ & $\%$ & $\%$ & $\%$ & $\%$ & $\%$ & $\%$ & $\%$ & $\%$ & $\%$ & $\%$ \\
\hline N/A & 1 & 1 & 1 & 8 & 1 & 1 & 3 & 2 & 2 & 3 & 1 & 9 & 9 & 6 & 3 & 0 & 3 & 0 & 0 & 0 & 3 & 0 & 3 & 0 & 0 & 0 & 0 & 0 \\
& 4 & 5 & 4 & $\%$ & 1 & 4 & 0 & 0 & 0 & 0 & 4 & $\%$ & $\%$ & $\%$ & 3 & $\%$ & 8 & $\%$ & $\%$ & $\%$ & 3 & $\%$ & 3 & $\%$ & $\%$ & $\%$ & $\%$ & $\%$ \\
& $\%$ & $\%$ & $\%$ & & $\%$ & $\%$ & $\%$ & $\%$ & $\%$ & $\%$ & $\%$ & & & & $\%$ & & $\%$ & & & & $\%$ & & $\%$ & & & & \\
\hline
\end{tabular}

